\title{
Reactions leading to the formation and breakdown of stilpnomelane in the Otago Schist, New Zealand
}

\author{
G. $\mathrm{LI}^{1,2}$ E. J. ESSENE, ${ }^{1}$ D. R. PEACOR ${ }^{1}$ AND D. S. $\mathrm{COOMBS}^{3}$ \\ ${ }^{1}$ Department of Geological Sciences, University of Michigan, Ann Arbor, Michigan, USA (drpeacor@umich.edu) \\ ${ }^{2}$ Department of Geology, Arizona State University, Tempe, Arizona, USA \\ ${ }^{3}$ Geology Department, University of Otago, Dunedin, New Zealand
}

\begin{abstract}
Semi-pelitic rocks ranging in grade from the prehnite-pumpellyite to the greenschist facies from southeastern Otago, New Zealand, have been investigated in order to evaluate the reactions leading to formation and breakdown of stilpnomelane. Detrital grains of mica and chlorite along with fine-grained authigenic illite and chlorite occur in lower-grade rocks with compactional fabric parallel to bedding. At higher grades, detrital grains have undergone dissolution, and metamorphic phyllosilicates have crystallized with preferred orientation (sub)parallel to bedding, leading to slaty cleavage. Stilpnomelane is found in metapelites of the pumpellyite-actinolite facies and the chlorite zone of the greenschist facies, but only rarely in the biotite zone of the greenschist facies. Illite or phengite is ubiquitous, whereas chlorite occurs only rarely with stilpnomelane upgrade of the pumpellyite-out isograd. Chemical and textural relationships suggest that stilpnomelane formed from chlorite, phengite, quartz, K-feldspar and iron oxides. Stilpnomelane was produced by grain-boundary replacement of chlorite and by precipitation from solution, overprinting earlier textures. Some relict $14 \AA$ chlorite layers are observed by TEM to be in the process of transforming to $12 \AA$ stilpnomelane layers. The AEM analyses show that Fe is strongly partitioned over $\mathrm{Mg}$ into stilpnomelane relative to chlorite $\left(K_{\mathrm{D}} \approx 2.5\right)$ and into chlorite relative to phengite $\left(K_{\mathrm{D}} \approx 1.9\right)$. Modified $\mathrm{A}^{\prime} \mathrm{FM}$ diagrams, projected from the measured phengite composition rather than from ideal $\mathrm{KAl}_{3} \mathrm{Si}_{3} \mathrm{O}_{10}(\mathrm{OH})_{2}$, are used to elucidate reactions among chlorite, stilpnomelane, phengite and biotite. In addition to pressure, temperature and bulk rock composition, the stilpnomelane-in isograd is controlled by variations in $\mathrm{K}, \mathrm{Fe}^{3+} / \mathrm{Fe}^{2+}, \mathrm{O} / \mathrm{OH}$ and $\mathrm{H}_{2} \mathrm{O}$ contents, and the locus of the isograd is expected to vary in rocks of different oxidation states and permeabilities. Biotite, quartz and less phengitic muscovite form from stilpnomelane, chlorite and phengite in the biotite zone. Projection of bulk rock compositions from phengite, $\mathrm{NaAlO}_{2}, \mathrm{SiO}_{2}$ and $\mathrm{H}_{2} \mathrm{O}$ reveals that they lie close to the polyhedra defined by the $\mathrm{A}^{\prime} \mathrm{FM}$ minerals and albite. Other extended A'FM diagrams, such as one projected from phengite, $\mathrm{NaAlO}_{2}, \mathrm{CaAl}_{2} \mathrm{O}_{4}, \mathrm{SiO}_{2}$ and $\mathrm{H}_{2} \mathrm{O}$, may prove useful in the evaluation of other low-grade assemblages.
\end{abstract}

Key words: AEM analysis; AFM diagram; chlorite; chlorite zone; phengite; stilpnomelane.

\section{INTRODUCTION}

Stilpnomelane is developed in iron formations and other rocks subjected to low-pressure metamorphism, and it is widespread in mafic, psammitic and pelitic rocks of the greenschist and blueschist facies. Its formation generally requires high $\mathrm{Fe} /(\mathrm{Fe}+\mathrm{Mg})$, although aluminous metapelites, even when rich in $\mathrm{Fe}$, may contain chloritoid rather than stilpnomelane, and K-rich rocks at grades higher than the biotite isograd usually have biotite instead.

Reactions involving the formation or breakdown of stilpnomelane have been proposed that involve other phyllosilicates (e.g. Brown, 1975). However, in typical low-grade rocks in which stilpnomelane first appears, phyllosilicates are very fine-grained, commonly $<2 \mu \mathrm{m}$ thick. As a result, size limitations cause data from optical microscopy, electron microprobe analyses and powder X-ray diffraction to give incomplete or misleading results. Details of reactions involving stilpnomelane

(C) Blackwell Science Inc., 0263-4929/00/ $\$ 15.00$

Journal of Metamorphic Geology, Volume 18, Number 4, 2000 and other phyllosilicates in such rocks, and their textural, structural and chemical evolution, are therefore still not well understood. With its capability of high-magnification imaging, transmission electron microscopy (TEM) can provide direct observation of textural relationships and stacking sequences of phyllosilicates. These relations may permit mechanisms of transformations to be identified, with definition of reactant and product phases. Selected area electron diffraction (SAED) and analytical electron microscopy (AEM) provide in situ structural and chemical data, respectively, on discrete phases as small as $100 \AA$ in diameter, allowing determination of compositions of co-existing phases and their variation on a submicroscopic scale (Peacor, 1992).

In southern New Zealand, stilpnomelane is often present, sometimes as a major constituent, in metagreywackes, metapelites and metabasites ranging from prehnite-pumpellyite facies to the biotite zone of the greenschist facies (e.g. Hutton, 1938; Brown, 1967). 
The term metapelite is here used for metasediments with relict clay- to silt-sized particles and their highergrade derivatives which are more phyllitic to schistose than adjacent coarse-grained metagreywackes. A prograde coastal section through these rocks in southeast Otago has provided material for the present study. In this, TEM, AEM and SAED techniques have been applied to characterize structural, chemical and textural relationships, especially of phengite, chlorite, stilpnomelane and biotite and their reactions in the stilpnomelane-bearing metapelites.

\section{GEOLOGICAL BACKGROUND}

In the South Island of New Zealand, greywackes and associated sediments of Permian to Jurassic age were folded and regionally metamorphosed during the Jurassic-Cretaceous to form the Haast Schist (Fig. 1). The Otago Schist is part of the Haast Schist; it consists of a complexly deformed pile of metapsammitic and metapelitic rocks, with minor metavolcanic and metachert horizons. These belong to at least two distinct

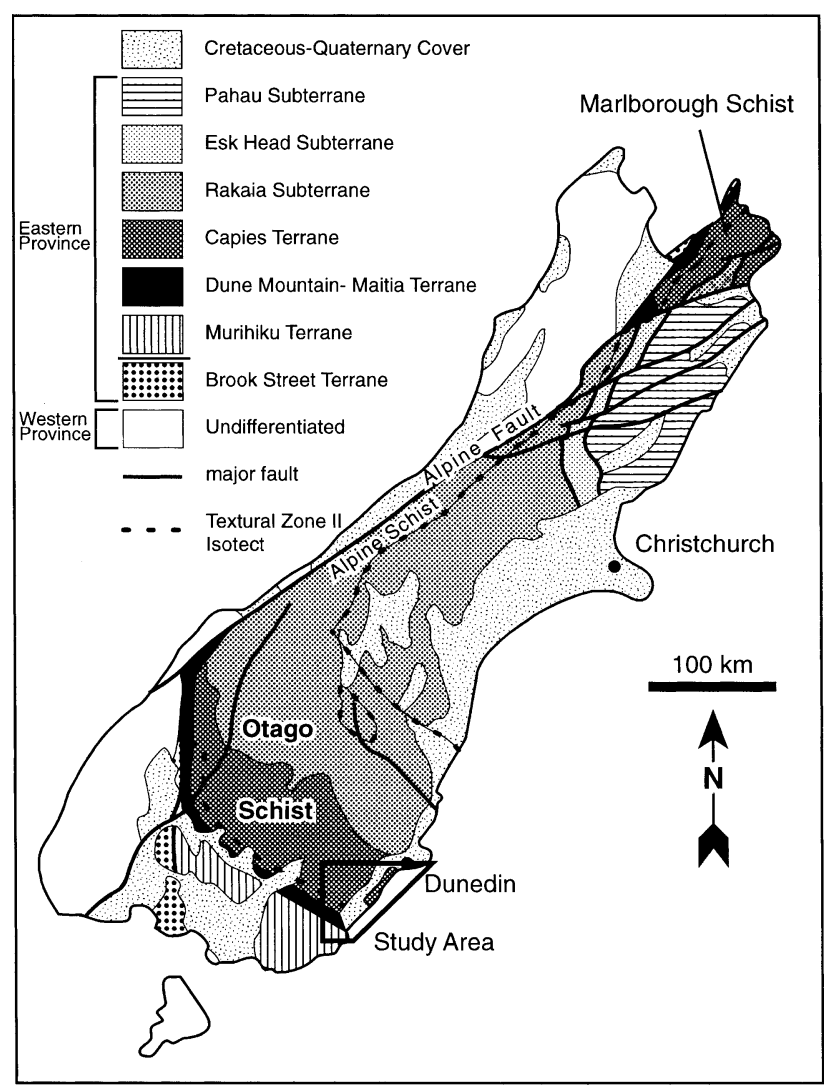

Fig. 1. Geological map of South Island, New Zealand, showing location of the study area south of Dunedin (after Mortimer, 1993). The Alpine Schist, Marlborough Schist and Otago Schist form the low- to medium-grade Haast Schist. The textural zone I-II isotect, much generalized, indicates the incoming of pervasive metamorphic foliation in psammites. This isotect overprints rocks of both the Torlesse and Caples Terranes. terranes, the Torlesse and Caples Terranes, which were sutured (Bishop et al., 1985; Roser \& Cooper, 1990) while subjected to a low-grade metamorphic overprint that did not exceed greenschist facies in most places. The Otago Schist passes north-westwards into the Alpine Schist in which the grade of metamorphism reaches the amphibolite facies. In Otago, the schists grade to the north-east and south-west into less metamorphosed parts of the Torlesse and Caples Terranes, respectively (Mortimer, 1993).

The Otago Schists were placed by Turner (1933) in the chlorite zone of the greenschist facies. They were subdivided on textural grounds, especially the development of penetrative foliation and segregation of quartzfeldspar laminae, into four chlorite subzones (Chl 1-4) of the greenschist facies (Turner, 1935; Hutton \& Turner, 1936). Subsequent work has shown, however, that the lower-grade rocks (Chl $1 \& 2$ subzones) formed in grades below that of the greenschist facies. Bishop (1972) revised the Turner-Hutton chlorite subzones into a series of textural zones (TZ I, IIA, IIB, IIIA, IIIB and IV) defined on the basis of features observable in the field for rocks of greywacke (psammitic) parentage. In TZ I, which is not included in the schist units, greywackes lack penetrative foliation. In TZ II, which forms the lowest-grade part of the Otago, Alpine and Haast Schists, greywackes are weakly to strongly foliated, and tend to split accordingly, but lack segregation laminae. In TZ III, greywacke derivatives are strongly foliated, fine-grained schists with thin and initially discontinuous segregation laminae; these become thicker and grain size tends to increase in TZ IV. Boundaries between the textural zones are referred to as isotects to distinguish them from isograds. Bishop (1972) found that isotects and isograds are not parallel on a regional scale, but in east Otago they are approximately parallel (Fig. 2). Here, TZ I is in the prehnite-pumpellyite facies; TZ II includes parts of the prehnite-pumpellyite and pumpellyite-actinolite facies; TZ IIIA includes parts of the pumpellyiteactinolite facies and the chlorite, and, in TZ IIIB near Brighton, biotite zones of the greenschist facies; TZ IV (north of Brighton outside Fig. 2) is also in the lower greenschist facies. Complex deformation involving transposition of bedding and repeated folding on many scales is a feature of the schists.

In south-east Otago (Fig. 2), metagreywackes, metapelites, and subordinate metabasites, metacherts and intercalated manganiferous lenses, increase in metamorphic grade from south-west to north-east. The textural grade of prehnite-pumpellyite rocks inland near Balclutha is TZ I, and it ranges along the coast from TZ IIA near Chrystalls Beach to TZ IIIB at Brighton. Neither prehnite nor actinolite has been reported as a neoformed metamorphic mineral in the southern part of TZ IIA near Chrystalls Beach, and it is unclear whether this part of the section is in the prehnite-pumpellyite or pumpellyite-actinolite facies. One sample, D11.1, contains minor lawsonite and 
Fig. 2. Geological map of the south-east Otago coastal section south of Dunedin (after Mortimer, 1993), showing the pattern of regional low-grade metamorphism. Sample locations are indicated by small solid circles with sample numbers.

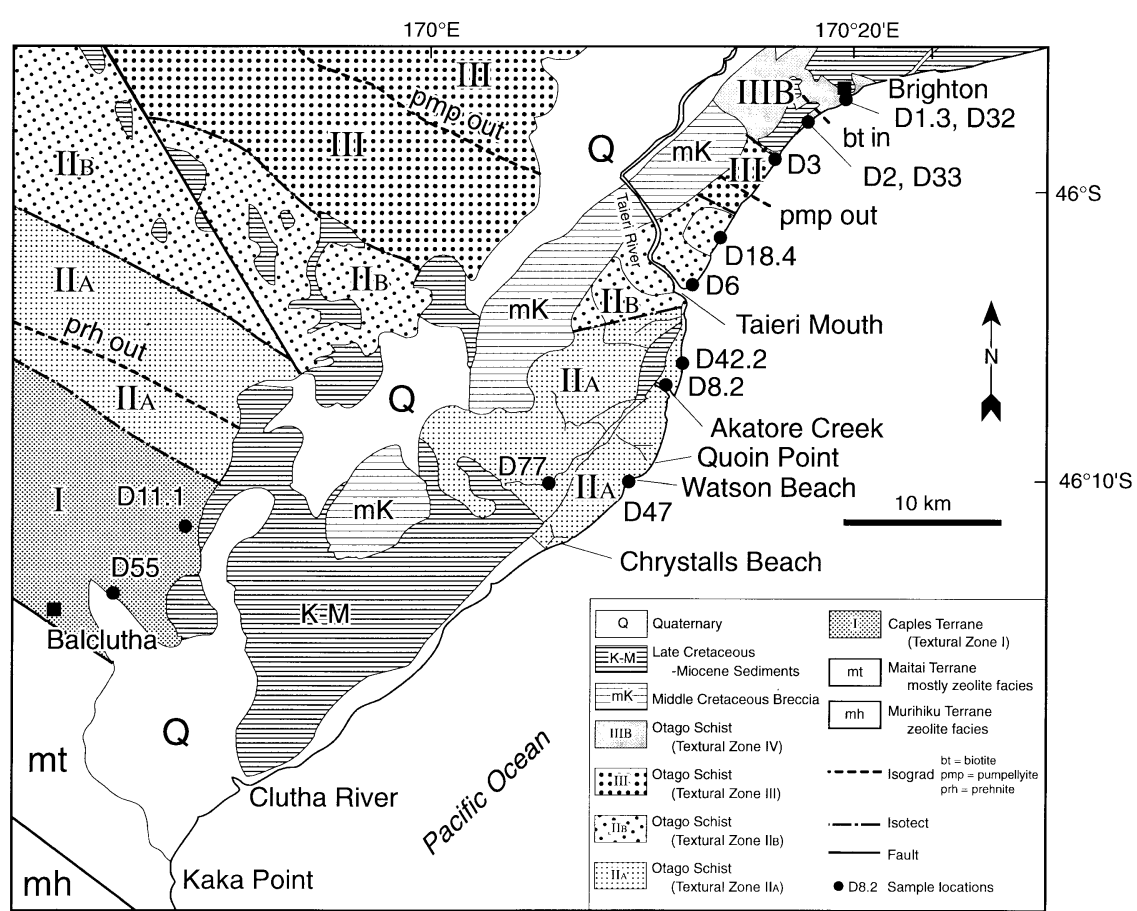

pumpellyite, indicating that there may be a narrow window of the lawsonite-albite-chlorite (sub)facies locally intervening between the prehnite-pumpellyite and pumpellyite-actinolite facies in the Otago Schists. Peak conditions for upper chlorite zone metamorphism in north-western Otago are estimated to have been at $390{ }^{\circ} \mathrm{C}$ and $4.5 \mathrm{kbar}$ (Yardley, 1982; Jamieson \& Craw, 1987); it is unlikely that they were very different in East Otago.

\section{SAMPLES EXAMINED AND ANALYTICAL METHODS}

A suite of 93 samples was collected from the prograde sequence within the Otago Schist and the Caples Terrane (Figs $1 \& 2$ ) for petrographic and other observations. Thirteen samples with maximum phyllosilicate contents were subsequently selected for the present study (Fig. 2, Table 1). Selection was designed to cover a large range of illite crystallinity in a prograde sequence as continuous and well-defined as possible in rocks with similar total $\mathrm{Fe} / \mathrm{Mg}$ ratios. The only dioctahedral phyllosilicates identified are illite and phengite. The 13 samples were analysed using an automated Philips X-ray fluorescence unit on fused rock powders (Table 2). Except for a hydrothermally altered rock (sample D1.3), the analyses are all similar in having a moderate peraluminous character and intermediate $\mathrm{Fe} / \mathrm{Mg}$ ratios. Although collected to maximize the phyllosilicate content, they are of semipelitic composition.

Powder XRD data were obtained for bulk rock samples of air-dried $<2 \mu \mathrm{m}$ separates with a Philips automated diffractometer with graphite monochromator and $\mathrm{Cu} K \alpha$ radiation to define the principal minerals and illite crystallinity indices. Polished thin sections were prepared for petrographic observations by SEM and optical microscopy, and sticky wax-mounted thin sections for TEM specimens. Thin sections were cut perpendicular to both bedding and cleavage to obtain

Table 1. Mineral assemblages in pelitic rocks from the eastern Otago coast section.

\begin{tabular}{|c|c|c|c|}
\hline Samples & Textural zone & Metamorphic facies & Minerals \\
\hline D55, D11.1 & TZ I & prehnite-pumpellyite facies & $\begin{array}{l}\text { illite/smectite, } 1 M_{\mathrm{d}} \text { illite, berthierine, chlorite, chlorite-mica stacks*, chlorite*, muscovite*, } \\
\text { quartz, albite, K-feldspar, apatite, pyrite, Fe-oxide, titanite, zircon }\end{array}$ \\
\hline D77, D47, D8.2, D42.2 & TZ IIA & pumpellyite-actinolite facies & $\begin{array}{l}1 M_{\mathrm{d}} \text { and } 2 M_{1} \text { illite, phengitic muscovite, chlorite-mica stacks*, chlorite*, muscovite*, quartz, } \\
\text { albite, pumpellyite, epidote, pyrite, Fe-oxide, apatite, titanite }\end{array}$ \\
\hline D6, D18.4 & TZ IIB & pumpellyite-actinolite facies & $\begin{array}{l}\text { phengite, stilpnomelane, nanosize relict chlorite, quartz, albite, epidote, apatite, titanite, } \\
\text { pyrite, zircon, pumpellyite }\end{array}$ \\
\hline D3 & TZ IIIA & chlorite zone greenschist facies & phengite, stilpnomelane, quartz, albite, epidote, apatite, titanite, pyrite, zircon \\
\hline D33, D2 & TZ IIIB & chlorite zone, greenschist facies & phengite, stilpnomelane, chlorite, quartz, albite, epidote, apatite, pyrite, Ti-oxide \\
\hline D32 & TZ IIIB & biotite zone, greenschist facies & phengite, chlorite, quartz, albite, epidote, pyrite, titanite, apatite, Fe-oxide, Ti-oxide \\
\hline D1.3 & TZ IIIB & biotite zone, greenschist facies & $\begin{array}{l}\text { phengite, biotite, kaolinite**, quartz, albite, epidote, calcite**, siderite, apatite, pyrite, } \\
\text { Fe-oxide, Ti-oxide, titanite }\end{array}$ \\
\hline
\end{tabular}

* detrital phyllosilicate; $* *$ hydrothermal alteration product. 
Table 2. XRF Analyses of a prograde sequence of metapelites from Otago, South Island, New Zealand.

\begin{tabular}{|c|c|c|c|c|c|c|c|c|c|c|c|c|c|}
\hline & \multicolumn{4}{|c|}{$\mathrm{TZ} \mathrm{I}$} & \multicolumn{3}{|c|}{ TZ IIA } & \multicolumn{2}{|c|}{ TZ IIB } & \multirow{2}{*}{$\frac{\text { TZ IIIA }}{\text { D33 }}$} & \multicolumn{3}{|c|}{ TZ IIIB } \\
\hline & D55 & D11.1 & D77 & D47 & D8.2 & D42.2 & D6 & D18.4 & D3 & & D2 & D32 & D1.3* \\
\hline $\mathrm{SiO}_{2}$ & 60.02 & 63.65 & 65.87 & 60.51 & 63.57 & 66.09 & 66.52 & 64.75 & 67.39 & 68.49 & 60.92 & 60.97 & 47.57 \\
\hline $\mathrm{TiO}_{2}$ & 0.85 & 0.78 & 0.60 & 0.81 & 0.76 & 0.60 & 0.64 & 0.68 & 0.75 & 0.61 & 0.85 & 0.61 & 1.28 \\
\hline $\mathrm{Al}_{2} \mathrm{O}_{3}$ & 18.58 & 16.14 & 15.10 & 17.85 & 17.26 & 16.63 & 15.43 & 16.38 & 15.81 & 15.42 & 18.58 & 17.79 & 21.03 \\
\hline $\mathrm{Fe}_{2} \mathrm{O}_{3}$ & 7.02 & 5.29 & 6.81 & 6.02 & 4.11 & 3.68 & 4.78 & 4.32 & 2.91 & 2.86 & 4.59 & 5.33 & 5.54 \\
\hline $\mathrm{MnO}$ & 0.09 & 0.07 & 0.14 & 0.09 & 0.06 & 0.19 & 0.08 & 0.07 & 0.07 & 0.08 & 0.12 & 0.10 & 0.09 \\
\hline $\mathrm{MgO}$ & 2.25 & 2.03 & 2.22 & 2.04 & 1.61 & 1.69 & 1.59 & 1.52 & 1.02 & 1.19 & 1.69 & 2.03 & 2.54 \\
\hline $\mathrm{CaO}$ & 1.38 & 2.93 & 0.34 & 1.17 & 1.57 & 0.36 & 1.01 & 1.07 & 0.84 & 0.77 & 1.13 & 1.52 & 4.51 \\
\hline $\mathrm{Na}_{2} \mathrm{O}$ & 1.59 & 2.55 & 2.70 & 3.57 & 3.49 & 3.05 & 3.86 & 3.98 & 5.19 & 5.23 & 5.48 & 5.17 & 1.79 \\
\hline $\mathrm{K}_{2} \mathrm{O}$ & 3.71 & 2.53 & 2.50 & 3.69 & 3.72 & 3.91 & 2.79 & 4.04 & 2.31 & 1.95 & 2.71 & 2.45 & 4.78 \\
\hline $\mathrm{P}_{2} \mathrm{O}_{5}$ & 0.13 & 0.11 & 0.11 & 0.53 & 0.14 & 0.12 & 0.12 & 0.11 & 0.12 & 0.11 & 0.12 & 0.10 & 0.26 \\
\hline LOI** & 3.83 & 3.91 & 3.12 & 2.83 & 2.64 & 2.90 & 2.20 & 2.44 & 2.31 & 1.92 & 2.26 & 3.33 & 9.97 \\
\hline Sum & 99.45 & 99.99 & 99.51 & 99.11 & 98.93 & 99.22 & 99.02 & 99.36 & 98.72 & 98.63 & 98.45 & 99.40 & 99.36 \\
\hline
\end{tabular}

* Hydrothermally altered sample; ** Loss on ignition, including $\mathrm{H}_{2} \mathrm{O}, \mathrm{CO}_{2}, \mathrm{~S}_{2}$ and some decrease due to oxidation of $\mathrm{FeO}$.

optimum orientation for SEM observations of textural relationships and to obtain TEM (001) lattice-fringe images of phyllosilicates. Following SEM study using back-scattered electron (BSE) imaging and energydispersive spectral (EDS) analysis, ion-milled specimens were prepared following the method described by Li et al. (1994). The TEM observations were made using a Philips CM12 scanning transmission electron microscope (STEM) fitted with a Kevex Quantum solid-state detector and computer system. The STEM was operated at an accelerating voltage of $120 \mathrm{kV}$ and a beam current of c. $10 \mathrm{nA}$. Quantitative chemical analyses were obtained by AEM and processed using the standards muscovite $(\mathrm{K}, \mathrm{Al})$, clinochlore $(\mathrm{Mg}, \mathrm{Al}$, $\mathrm{Fe})$, albite $(\mathrm{Na}, \mathrm{Al})$, fayalite $(\mathrm{Fe})$, rhodonite $(\mathrm{Mn}, \mathrm{Fe}$, $\mathrm{Ca})$ and titanite $(\mathrm{Ti}, \mathrm{Ca})$ to derive $k$-ratios, which were utilized to process EDS data assuming the thin-foil approximation (Cliff \& Lorimer, 1975).

\section{RESULTS}

\section{Petrographic observations}

Table 1 is a summary of the mineral assemblages of the studied samples as determined by XRD, optical microscopy and SEM. Illite crystallinity indices ranged from $0.56^{\circ} \Delta 2 \Theta$ within the prehnite-pumpellyite facies to $0.14^{\circ}$ in the biotite zone of the greenschist facies, with a generally good correlation between decreasing illite crystallinity indices and increasing metamorphic grade ( $\mathrm{Li}, 1996)$. The diagenetic zone, anchizone and epizone of illite crystallinity thus correspond approximately with the prehnite-pumpellyite, pumpellyiteactinolite and greenschist facies, respectively, in the south-east Otago section, with the limits of anchizonal metamorphism near the TZ I-IIA and TZ IIAIIB isotects.

In the lower-grade rocks, especially those of the prehnite-pumpellyite facies in TZ I, aggregates of very fine-grained authigenic illite and chlorite (often not resolvable by SEM) comprise the matrix, with a compactional bedding-parallel fabric. Quartz, feldspar, phengite, chlorite and biotite occurring as larger grains are the principal detrital minerals, and are enclosed within a fine-grained matrix of phyllosilicates. An intense tectonic fabric occurs in the lower-grade part of TZ IIA, with framework silicates occurring as very flattened lenses of fine-grained quartz and albite. Detrital phyllosilicate grains are less regular in shape than their diagenetic equivalents. Matrix phyllosilicates have a strong preferred orientation parallel to cleavage, which is commonly parallel or subparallel to bedding. In the higher-grade part of TZ IIA, grains of neoformed illite/phengite and chlorite are still larger, and detrital phyllosilicates are only rarely observed (Fig. 3).

At higher grades, the rocks are strongly foliated with a prominent lineation, preferred orientation of flattened quartz and phyllosilicates, and a crenulation cleavage that is usually parallel to or at a low angle to bedding. Stilpnomelane commonly occurs as sheaves of platy crystals. Co-existing stilpnomelane and phengite in TZ IIB are relatively coarse (Fig. 4). Stilpnomelane but not chlorite was observed by SEM in samples from TZ IIB and TZ IIIA. However, some neoformed chlorite was observed in samples from the

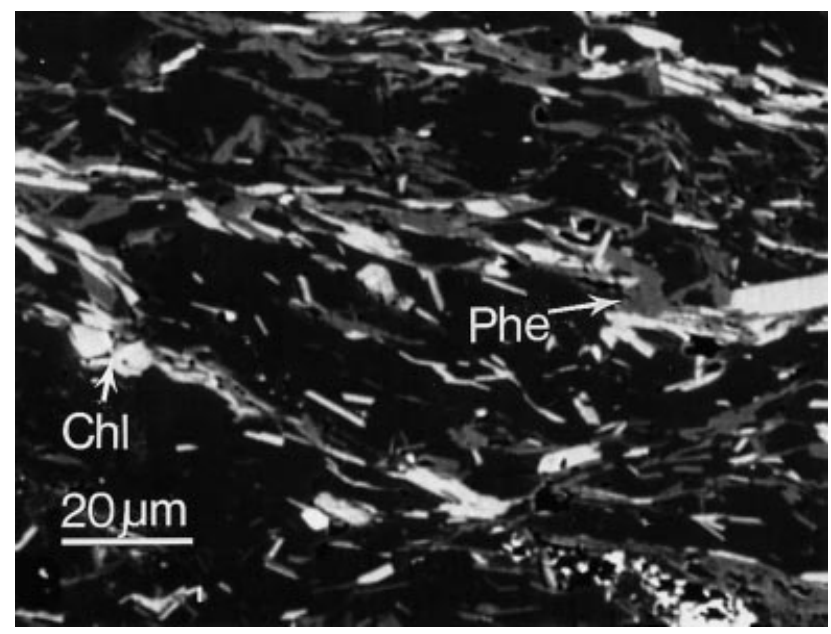

Fig. 3. BSE image of sample D8.2 (pumpellyite-actinolite facies, TZ IIA) with neoformed phengite (Phe) and chlorite (Chl). Detrital chlorite and phengite are rarely observed. 


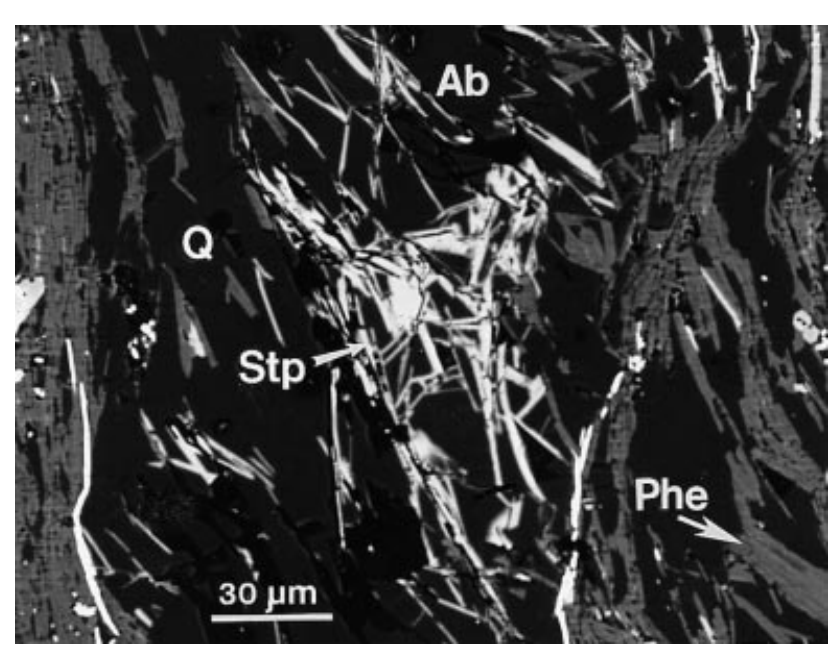

Fig. 4. BSE image of sample D18.4 (pumpellyite-actinolite facies, TZ IIB) with aggregates of coarse-grained phengite and stilpnomelane (Stp) with a typical sheaf-like shape. Ab, albite; $\mathrm{Q}$, quartz.

chlorite zone of TZ IIIB. Large grains of neoformed chlorite co-exist with phengite, quartz and albite in sample D32, which is from the biotite zone of TZ IIIB. However, neither biotite nor stilpnomelane was found in this sample. In sample D1.3 from the biotite zone, phengite and biotite have sharply defined subhedral outlines and grains are much larger than those of phyllosilicates of lower grades, and no stilpnomelane or chlorite was detected. The coarse-grained phengite and biotite are intimately associated with albite and quartz (Fig. 5). Both phengite and biotite have been partially kaolinitized by hydrothermal fluids in this sample (Craw et al., 1982; Ahn \& Peacor, 1987; Jiang \& Peacor, 1991).

Overall, the XRD, illite crystallinity, optical and SEM data on phyllosilicate minerals in the eastern

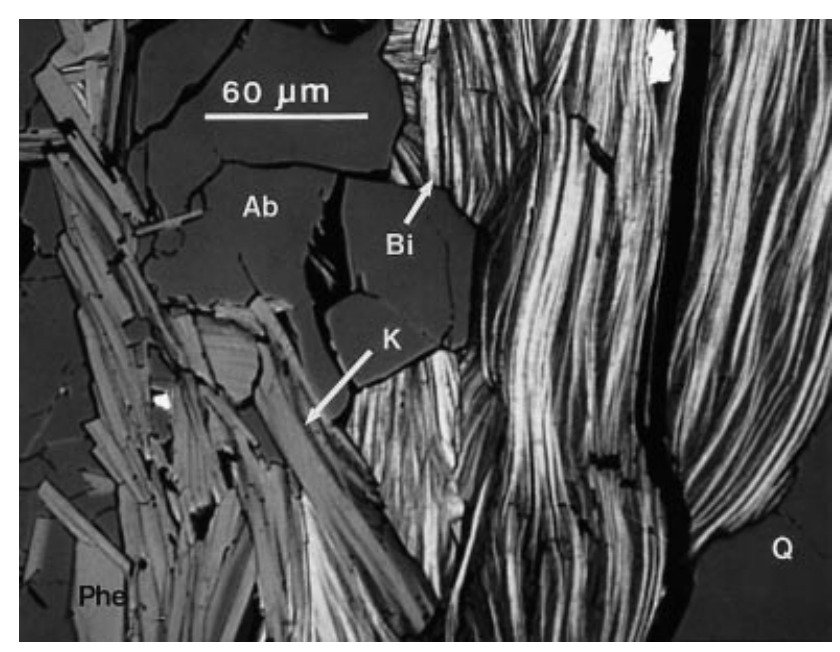

Fig. 5. BSE image of large biotite ( $\mathrm{Bi}$ ) and phengite grains in the biotite zone (sample D1.3). Both biotite and phengite are partially kaolinitized and intergrown with kaolinite $(\mathrm{K}$; dark contrast).
Otago section are consistent with changes involving diagenesis of detrital minerals and neocrystallization and growth of metamorphic minerals. The shapes of grains trend from anhedral toward euhedral, and the grain sizes of phyllosilicates all increase with the metamorphic grade. Illite or phengite is present in rocks of all grades. Chlorite is present, sometimes only as nanosize relicts, below TZ III, but is usually absent in stilpnomelane-bearing rocks of TZ III, and occurs again in TZ IIIB. Stilpnomelane occurs in the pumpellyite-actinolite facies and the chlorite zone of the greenschist facies, but it is found only rarely beyond the biotite isograd.

\section{TEM observations}

Seven representative samples (D8.2, D6, D18.4, D3, D33, D2 \& D1.3) were chosen for TEM study. The data presented here were all obtained from diagenetic and metamorphic phyllosilicates rather than detrital grains. Lattice-fringe images of co-existing chlorite and phengite in sample D8.2 (TZ IIA) show that white micas occur as well-defined and relatively large, defectfree packets, with $2 M_{1}$ polytypism and cationic charge near that of ideal muscovite. All of these characteristics are typical of neoformed mica of metamorphic origin. By contrast, illite of lower-grade rocks occurs in thin packets as the $1 M_{\mathrm{d}}$ polytype with phengitic composition and a low net negative charge $\left(<1.5\right.$ per $\left.\mathrm{O}_{20}[\mathrm{OH}]_{4}\right)$, characteristics that are typical of authigenic illite.

Stilpnomelane is present in almost all of the highergrade rocks collected from the pumpellyite-actinolite facies of TZ IIB. It commonly occurs as thick packets of $12 \AA$ layers with discrete tabular crystal shapes, with the longest dimensions of tabular crystals randomly oriented and forming sheaf-like bundles (e.g. Fig. 6). Figure 7 is a low-magnification TEM image of phyllosilicates in sample D6 of the pumpellyite-

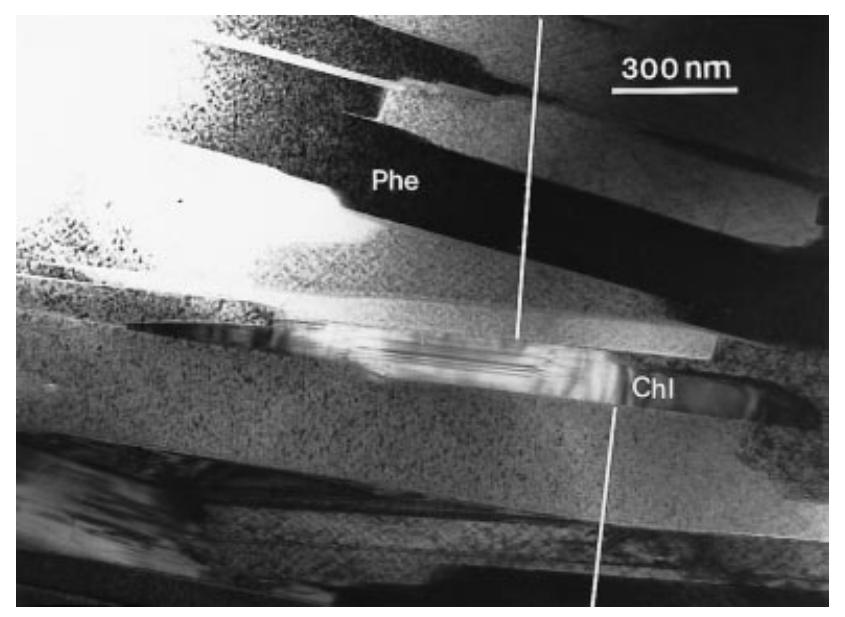

Fig. 6. TEM lattice-fringe image of sample D6 (pumpellyiteactinolite facies, TZ IIB) showing an aggregate of subparallel packets of stilpnomelane displaying interlocking textures with low-angle boundaries. 
actinolite facies in TZ IIB. A lens-shaped grain of relict chlorite about $130 \mathrm{~nm}$ wide is armoured by relatively thick phengite packets, and the elongated chlorite crystal has step-like crystal boundaries in contact with the surrounding phengite, implying decomposition of chlorite and growth of stilpnomelane. A TEM latticefringe image of sample D18.4 shows an irregular reaction front between chlorite and stilpnomelane (Fig. 8). Relatively deformed $14 \AA$ chlorite layers are transformed to straight and undeformed $12 \AA$ stilpnomelane layers, the layers of reactant chlorite being at a low angle of about $20^{\circ}$ to the layers of product stilpnomelane. At the apparent reaction front, the layers of phyllosilicates are twisted and deformed, and layer terminations are frequently observed (indicated by white arrows). Where the reaction front is nearly perpendicular to both chlorite and stilpnomelane layers (e.g. the lower left part of Fig. 8), six chlorite layers $(6 \times 14 \AA)$ are observed to transform to seven stilpnomelane layers $(7 \times 12 \AA)$, a volume-conserving relation which is consistent with minimal interface stress. However, where the reaction front is at a low angle to
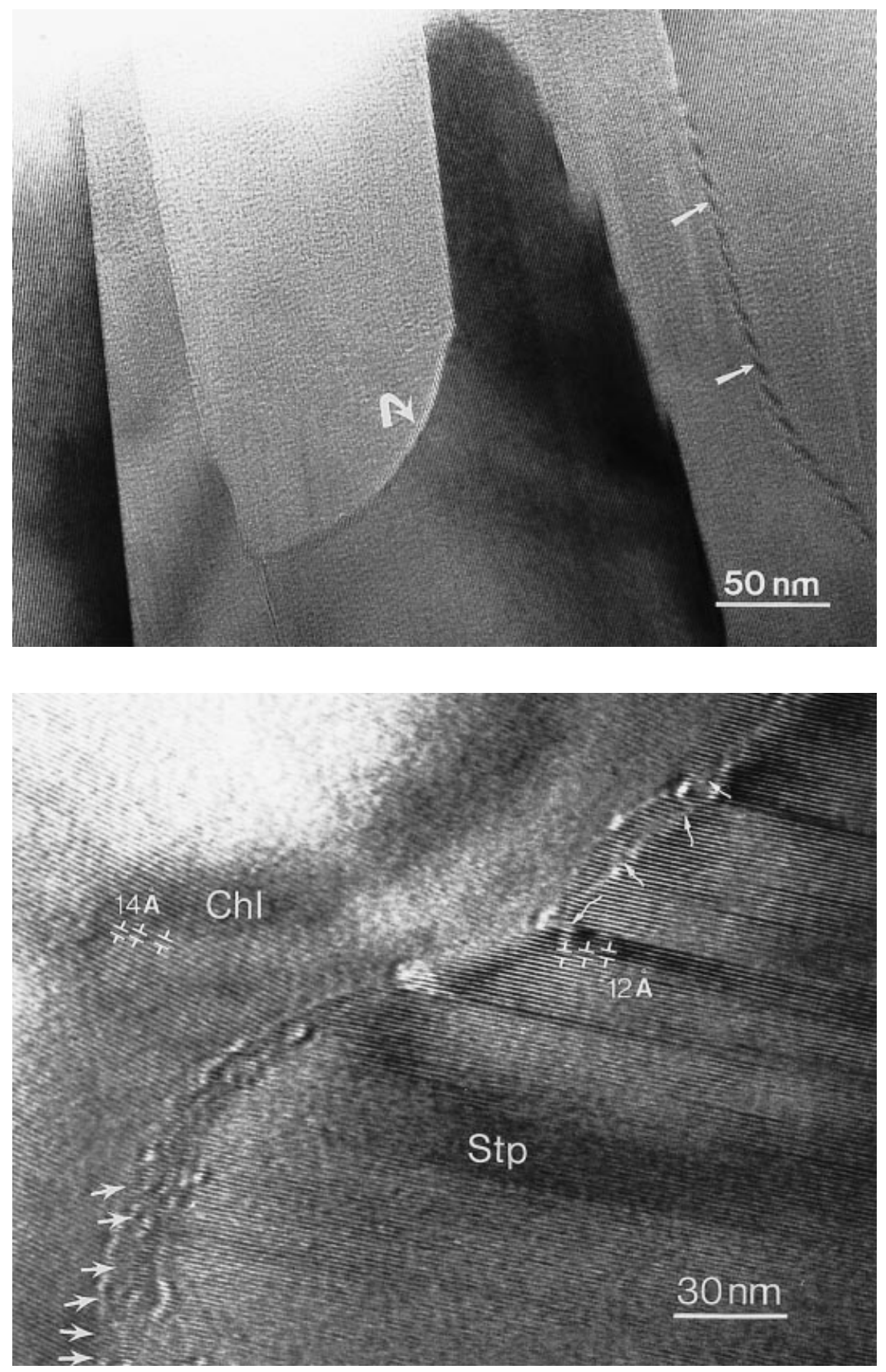

Fig. 7. Low-magnification TEM image of phyllosilicates in sample D6 showing that a lens-shaped relict chlorite about $130 \mathrm{~nm}$ wide is armoured by relatively thick phengite packets (indicated by white bars). There are step-like crystal boundaries between chlorite and phengite.
Fig. 8. TEM lattice-fringe image shows an irregular reaction front about $20 \mathrm{~nm}$ thick between chlorite and stilpnomelane in sample D18.4. Layer terminations (indicated by white arrows) are frequently observed at the reaction front. Approximately six relatively deformed 14 A chlorite layers are transformed to seven straight and undeformed $12 \AA$ stilpnomelane layers. 
layers (e.g. middle left of Fig. 8), the layer transformation of chlorite to stilpnomelane seems to have a oneto-one relationship. In some higher-grade rocks, chlorite is so rarely observed that only subnanometre-sized relicts can be seen. Figure 9 shows a TEM lattice fringe image with a few layers of $14 \AA$ chlorite among dominant stilpnomelane layers, and $14 \AA$ chlorite layers apparently in the process of transforming to $12 \AA$ stilpnomelane layers along packet boundaries. No chlorite was observed in the semi-pelitic rocks of chlorite zone TZ IIIA selected for TEM study.

The textural relationships among chlorite, phengite and stilpnomelane collectively imply a reaction of chlorite to produce stilpnomelane and phengite in TZ IIB and IIIA rocks. As shown in SEM images, nonetheless, chlorite is associated with phengite in rocks of the chlorite zone, TZ IIIB, and in biotite-free rocks (e.g. sample D32) of the biotite zone, TZ IIIB. Stilpnomelane is absent in the highest-grade rocks of this study which occur in the biotite zone. Large grains of biotite and phengite of metamorphic origin occur as aggregates of parallel to subparallel packets, each ranging from a few tens to a hundred nanometres in thickness as typical of epizone metamorphism.

\section{AEM analyses}

Representative AEM analyses of chlorite in rocks from TZ IIA and higher grades are listed in Table 3. Although AEM analyses are less accurate than electron microprobe analyses, AEM data were obtained in this study as most analysed grains had sizes less than the minimum required for electron microprobe analysis. The analyses were normalized to $28 \mathrm{O}$ atoms assuming that all iron is ferrous. The chlorite formulae have nearly equal numbers of tetrahedral and octahedral $\mathrm{Al}$ and nearly complete octahedral occupancy, consistent with only small amounts of $\mathrm{Fe}^{3+}$ and typical of chlorite of higher grades which has no mixed layers of other phases (Jiang et al., 1994). The $\mathrm{Al} /(\mathrm{Al}+\mathrm{Si})$ ratio of the chlorite is nearly constant, whereas the $\mathrm{Fe} /(\mathrm{Fe}+\mathrm{Mg})$ ratio decreases from 0.72 to 0.53 with increasing metamorphic grade. The chemical composition of chlorite (magnesian chamosite) is nearly constant within each grain and from grain to grain in samples from the same metamorphic grade, implying an approach to equilibrium.

Due to the relatively open structure of stilpnomelane, $\mathrm{K}$ can migrate toward the electron beam during microprobe analysis, resulting in increased $\mathrm{K}$ counts with increasing counting time (Craw, 1981). By contrast, the $\mathrm{K}$ in stilpnomelane and muscovite diffuses away from the electron beam during AEM analysis (Li, 1996). The loss of alkali cations by electron-beam irradiation during AEM analyses has been discussed (Ahn et al., 1986; van der Pluijm et al., 1988). The method proposed by van der Pluijm et al. (1988) to minimize $\mathrm{K}$ diffusion during analysis of stilpnomelane was applied in this study. The AEM analyses of stilpnomelane (Table 4) were normalized to 15 tetrahedral and octahedral cations by analogy with the approximation to the structural formula of stilpnomelane proposed by Eggleton \& Chappell (1978): $\mathrm{K}_{0.6}\left(\mathrm{Mg}, \mathrm{Fe}^{2+} \mathrm{Fe}^{3+}\right)_{6} \mathrm{Si}_{8} \mathrm{Al}(\mathrm{O}, \mathrm{OH})_{27} \cdot 2-4 \mathrm{H}_{2} \mathrm{O}$.

The $\mathrm{K}_{2} \mathrm{O}$ content as analysed in this study for east Otago stilpnomelane varies from 1.0 to $2.9 \mathrm{wt} \%$, corresponding to $0.21-0.62 \mathrm{pfu} \mathrm{K}$, but is mostly within the range $0.35-0.55 \mathrm{pfu}$. The $\mathrm{K}$ content may decrease slightly with increasing grade. Craw (1981) reported greater variations in the measured $\mathrm{K}_{2} \mathrm{O}$ of stilpnomelane from the Otago Schist, from 0.3 to $5.8 \mathrm{wt} \%$. Low $\mathrm{K}$ contents were ascribed to leaching of $\mathrm{K}$ by oxidation

Fig. 9. TEM lattice-fringe image of sample D18.4 showing a few layers of $14 \AA$ chlorite within dominant $12 \AA$ stilpnomelane layers. $14 \AA$ chlorite layers are also observed to transform to $12 \AA$ stilpnomelane layers, implying a reaction in which chlorite reacts to form stilpnomelane.

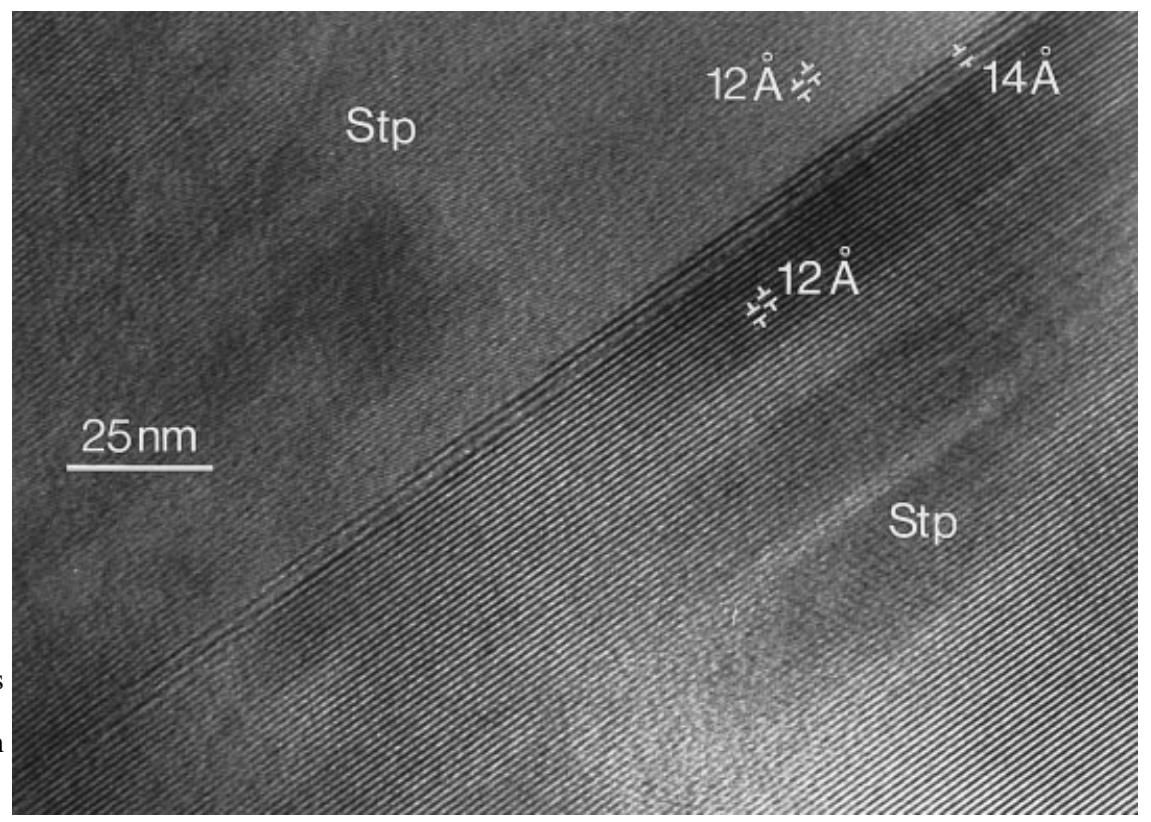




\begin{tabular}{|c|c|c|c|c|c|c|c|c|c|c|c|c|}
\hline & \multicolumn{3}{|c|}{ D8.2, TZ IIA } & \multicolumn{3}{|c|}{ D6, TZ IIB } & \multicolumn{3}{|c|}{ D33, TZ IIIB } & \multicolumn{3}{|c|}{ D2, TZ IIIB } \\
\hline & 1 & 2 & $x^{* *}$ & 1 & 2 & $x$ & 1 & 2 & $x$ & 1 & 2 & $x$ \\
\hline $\mathrm{Si}$ & 5.49 & 5.57 & 5.55 & 5.55 & 5.67 & 5.61 & 5.58 & 5.54 & 5.52 & 5.45 & 5.55 & 5.45 \\
\hline $\mathrm{Al}^{\mathrm{IV}}$ & 2.51 & 2.43 & 2.45 & 2.45 & 2.33 & 2.39 & 2.42 & 2.46 & 2.48 & 2.55 & 2.45 & 2.55 \\
\hline $\mathrm{Al}^{\mathrm{VI}}$ & 2.75 & 2.45 & 2.67 & 2.61 & 2.49 & 2.65 & 2.41 & 2.33 & 2.52 & 2.55 & 2.59 & 2.55 \\
\hline $\mathrm{Fe}^{2+}$ & 5.77 & 6.77 & 6.10 & 5.69 & 6.02 & 5.58 & 5.23 & 5.11 & 5.18 & 5.24 & 4.86 & 5.04 \\
\hline $\mathrm{Mn}$ & 0.24 & 0.15 & 0.21 & 0.11 & 0.16 & 0.13 & 0.17 & 0.15 & 0.16 & 0.17 & 0.19 & 0.18 \\
\hline $\mathrm{Mg}$ & 3.13 & 2.62 & 2.91 & 3.50 & 3.26 & 3.35 & 4.19 & 4.40 & 4.12 & 4.04 & 4.37 & 4.23 \\
\hline$X_{\mathrm{Al}}$ & 0.49 & 0.47 & 0.48 & 0.48 & 0.46 & 0.47 & 0.46 & 0.46 & 0.47 & 0.48 & 0.48 & 0.48 \\
\hline$X_{\mathrm{Fe}}$ & 0.65 & 0.72 & 0.68 & 0.62 & 0.65 & 0.63 & 0.56 & 0.54 & 0.56 & 0.57 & 0.53 & 0.54 \\
\hline
\end{tabular}

Table 3. Representative formulae for chlorite based on AEM analyses.*

* All Fe is calculated as FeO. Each formula is normalized on the basis of $28 \mathrm{O}$ atoms. Two standard deviations on the basis of counting statistics are $0.10-0.15$ pfu for $\mathrm{Si}, 0.06-0.08$ and $0.08-0.10$ pfu for $\mathrm{Al}^{\mathrm{IV}}$ and $\mathrm{Al}^{\mathrm{VI}}$, respectively, $0.29-0.43$ pfu for $\mathrm{Fe}, 0.21-0.34 \mathrm{pfu}$ for $\mathrm{Mg}, 0.01-0.04$ pfu for $\mathrm{Mn} . X_{\mathrm{Al}}=\mathrm{Al} /(\mathrm{Al}+\mathrm{Si}), X_{\mathrm{Fe}}=\mathrm{Fe} /(\mathrm{Fe}+\mathrm{Mg}) .{ }^{* *}$ Average of more than 20 AEM analyses.

Table 4. Representative formulae for stilpnomelane based on AEM analyses.*

\begin{tabular}{|c|c|c|c|c|c|c|c|c|c|c|c|c|c|c|c|}
\hline & \multicolumn{3}{|c|}{ D6, TZ IIB } & \multicolumn{3}{|c|}{ D18.4, TZ IIB } & \multicolumn{3}{|c|}{ D3, TZ IIIA } & \multicolumn{3}{|c|}{ D33, TZ IIIB } & \multicolumn{3}{|c|}{ D2, TZ IIIB } \\
\hline & 1 & 2 & $x^{* *}$ & 1 & 2 & $x$ & 1 & 2 & $x$ & 1 & 2 & $x$ & 1 & 2 & $x$ \\
\hline $\mathrm{Si}$ & 8.20 & 8.06 & 8.27 & 8.40 & 8.12 & 8.38 & 8.17 & 8.23 & 8.36 & 8.37 & 7.98 & 8.23 & 8.37 & 8.11 & 8.35 \\
\hline $\mathrm{Al}^{\mathrm{IV}}$ & 0.80 & 0.94 & 0.73 & 0.60 & 0.88 & 0.62 & 0.83 & 0.77 & 0.64 & 0.63 & 1.02 & 0.77 & 0.63 & 0.89 & 0.65 \\
\hline $\mathrm{Al}^{\mathrm{VI}}$ & 0.73 & 0.29 & 0.76 & 0.76 & 0.41 & 0.72 & 0.43 & 0.65 & 0.78 & 0.78 & 0.25 & 0.65 & 0.73 & 0.46 & 0.76 \\
\hline $\mathrm{Fe}^{2+}$ & 4.14 & 4.30 & 4.12 & 4.15 & 4.03 & 4.11 & 4.00 & 3.97 & 3.81 & 3.85 & 3.95 & 3.82 & 3.65 & 3.73 & 3.76 \\
\hline $\mathrm{Mn}$ & 0.16 & 0.14 & 0.16 & 0.14 & 0.20 & 0.19 & 0.20 & 0.26 & 0.23 & 0.22 & 0.23 & 0.28 & 0.18 & 0.21 & 0.19 \\
\hline $\mathrm{Mg}$ & 0.97 & 1.27 & 0.96 & 0.95 & 1.36 & 0.98 & 1.37 & 1.12 & 1.18 & 1.15 & 1.54 & 1.25 & 1.44 & 1.60 & 1.29 \\
\hline $\mathrm{Na}$ & n.d. $* * *$ & n.d. & n.d. & n.d. & 0.01 & 0.02 & n.d. & n.d. & n.d. & n.d. & n.d. & n.d. & n.d. & n.d. & n.d. \\
\hline K & 0.56 & 0.48 & 0.61 & 0.46 & 0.52 & 0.54 & 0.53 & 0.41 & 0.53 & 0.37 & 0.61 & 0.52 & 0.32 & 0.42 & 0.51 \\
\hline$X_{\mathrm{Al}}$ & 0.16 & 0.15 & 0.15 & 0.14 & 0.16 & 0.14 & 0.15 & 0.14 & 0.14 & 0.14 & 0.15 & 0.15 & 0.14 & 0.14 & 0.11 \\
\hline$X_{\mathrm{Fe}}$ & 0.81 & 0.77 & 0.81 & 0.81 & 0.75 & 0.81 & 0.74 & 0.78 & 0.76 & 0.77 & 0.72 & 0.75 & 0.72 & 0.70 & 0.74 \\
\hline
\end{tabular}

* All Fe is calculated as FeO. Each formula is normalized on the basis of 15 IV and VI cations. Two standard deviations on the basis of counting statistics are 0.13-0.19 pfu for Si, 0.04-0.06 pfu for Al, 0.21-0.32 pfu for Fe, 0.07-0.14 pfu for $\mathrm{Mg}, 0.01-0.02$ pfu for $\mathrm{Na}$ and $0.03-0.05$ pfu for $\mathrm{K} . X_{\mathrm{Al}}=\mathrm{Al} /(\mathrm{Al}+\mathrm{Si}), X_{\mathrm{Fe}}=\mathrm{Fe} /(\mathrm{Fe}+\mathrm{Mg})$. ** Average of more than 20 AEM analyses. ${ }^{* * *}$ n.d., not detected.

of $\mathrm{Fe}$ during weathering and high $\mathrm{K}$ contents to mobility of K under the electron beam. Brown (1971) obtained $\mathrm{K}_{2} \mathrm{O}$ contents as high as $3.3 \mathrm{wt} \%$, and even higher contents have been reported in stilpnomelane from iron formations (Miyano \& Miyano, 1982). Stilpnomelane in all samples of this study is very Fe-rich and is somewhat more aluminous than the above formula. As with chlorite, the stilpnomelane of eastern Otago pelites has an appreciable range of $\mathrm{Fe} /(\mathrm{Fe}+\mathrm{Mg})$ and a small variation in $\mathrm{Al} /(\mathrm{Al}+\mathrm{Si})$; individual grains and different grains in samples from the same metamorphic grade are relatively homogeneous. The $\mathrm{Fe} /(\mathrm{Fe}+\mathrm{Mg})$ ratio of stilpnomelane in lower-grade rocks is high (up to 0.85 ), and there is a general trend of decreasing $\mathrm{Fe} /(\mathrm{Fe}+\mathrm{Mg})$ ratio with increasing grade. The $\mathrm{Fe} /(\mathrm{Fe}+\mathrm{Mg})$ and $\mathrm{Al} /(\mathrm{Al}+\mathrm{Si})$ ratios of the stilpnomelane analyses are similar to those of Brown (1967).

Representative analyses of micas from the different textural zones are provided in Table 5. The chemical composition of phengite in samples from below the biotite zone of the eastern Otago schist was discussed in detail by Li (1996). The AEM data indicate that phengite in the biotite zone rock D1.3 has 6.49-6.65 pfu Si, $\mathrm{Al} /(\mathrm{Al}+\mathrm{Si})$ of $c .0 .41$ and $\mathrm{Fe} /(\mathrm{Fe}+\mathrm{Mg})$ of $0.40-0.47$. It is less phengitic than those in the pumpellyite-actinolite facies and chlorite zone. The phengite composition is relatively homogeneous within and between grains, in contrast with the large variations within a thin section or even within a single grain reported by Brown (1967).

The AEM analyses of biotite with low $\mathrm{K}_{2} \mathrm{O}$ contents and high calculated $\mathrm{Fe}^{3+} / \mathrm{Fe}^{2+}$ ratios were inferred to be perturbed as a result of alteration to kaolinite and were discarded. Less altered biotite has $\mathrm{Al} /(\mathrm{Al}+\mathrm{Si})$ of $0.31-0.35, \mathrm{Fe} /(\mathrm{Fe}+\mathrm{Mg})$ of $0.46-0.60$, and low $\mathrm{Ti}$, similar to the electron microprobe analyses of Brown (1967) and Craw et al. (1982). The low Ti contrasts with biotite analyses from higher-grade portions of the biotite zone, in which $0.14-0.16$ pfu Ti was reported (Brown, 1967).

\section{DISCUSSION}

\section{First appearance of stilpnomelane}

In the survey of 93 pelitic samples collected from the east Otago coastal section in this study, stilpnomelane is virtually ubiquitous from Taieri Mouth to near Brighton. It occurs in a sequence of progressively increasing grade from the pumpellyite-actinolite to chlorite zone of the greenschist facies, TZ IIB to TZ IIIB, but it is absent in almost all pelites from lower or higher grade. However, it is present in lowgrade TZ IIA metagreywacke about $3.2 \mathrm{~km} \mathrm{NE}$ of the southernmost exposures at Chrystalls Beach. Athough 
Table 5. Representative formulae for phengite and biotite based on AEM data.*

\begin{tabular}{|c|c|c|c|c|c|c|c|c|c|c|c|c|c|c|}
\hline & \multicolumn{10}{|c|}{ Phengite } & \multirow{2}{*}{\multicolumn{4}{|c|}{$\frac{\text { Biotite }}{\text { TZIIIB (D1.3) }}$}} \\
\hline & \multirow{2}{*}{$\frac{\text { TZIIA }}{\mathrm{D} 8.2^{* *}}$} & \multicolumn{2}{|c|}{ TZIIB } & \multirow{2}{*}{$\frac{\text { TZIIIA }}{\mathrm{D}^{* *}}$} & \multicolumn{2}{|c|}{ TZIIIB } & \multicolumn{4}{|c|}{ TZIIIB (D1.3) } & & & & \\
\hline & & $\mathrm{D} 6 * *$ & D18.4** & & D33** & $\mathrm{D} 2 * *$ & 1 & 2 & 3 & $x^{* *}$ & 1 & 2 & 3 & $x^{* *}$ \\
\hline $\mathrm{Si}$ & 6.83 & 6.82 & 6.86 & 6.75 & 6.54 & 6.55 & 6.60 & 6.49 & 6.60 & 6.59 & 6.04 & 6.29 & 5.92 & 6.12 \\
\hline $\mathrm{Al}^{\mathrm{IV}}$ & 1.17 & 1.18 & 1.14 & 1.25 & 1.46 & 1.45 & 1.40 & 1.51 & 1.40 & 1.41 & 1.96 & 1.71 & 2.08 & 1.88 \\
\hline $\mathrm{Al}^{\mathrm{VI}}$ & 3.12 & 3.04 & 3.07 & 3.03 & 3.00 & 2.85 & 3.06 & 2.96 & 3.11 & 2.99 & 1.12 & 1.12 & 1.14 & 1.14 \\
\hline $\mathrm{Ti}$ & n.d.*** & n.d. & n.d. & n.d. & n.d. & n.d. & 0.05 & 0.02 & 0.05 & 0.03 & n.d. & 0.02 & n.d. & 0.01 \\
\hline $\mathrm{Fe}^{2+}$ & 0.41 & 0.48 & 0.47 & 0.41 & 0.42 & 0.49 & 0.42 & 0.43 & 0.34 & 0.43 & 2.10 & 2.50 & 2.19 & 2.17 \\
\hline $\mathrm{Mn}$ & n.d. & n.d. & n.d. & n.d. & n.d. & n.d. & n.d. & n.d. & n.d. & n.d. & 0.08 & 0.05 & 0.06 & 0.07 \\
\hline $\mathrm{Mg}$ & 0.47 & 0.48 & 0.46 & 0.56 & 0.58 & 0.66 & 0.47 & 0.59 & 0.50 & 0.54 & 2.44 & 1.85 & 2.46 & 2.32 \\
\hline $\mathrm{Ca}$ & n.d. & n.d. & n.d. & n.d. & n.d. & n.d & n.d. & n.d. & n.d. & n.d. & n.d. & 0.01 & n.d. & n.d. \\
\hline $\mathrm{Na}$ & n.d. & n.d. & n.d. & 0.09 & 0.09 & 0.09 & n.d. & 0.16 & n.d. & n.d. & 0.04 & n.d. & n.d. & 0.01 \\
\hline $\mathrm{K}$ & 1.73 & 1.76 & 1.82 & 1.75 & 1.82 & 1.80 & 1.54 & 1.80 & 1.83 & 1.72 & 1.76 & 1.86 & 1.73 & 1.78 \\
\hline$\Sigma \mathrm{A}$ & 1.73 & 1.76 & 1.82 & 1.84 & 1.91 & 1.89 & 1.54 & 1.96 & 1.83 & 1.72 & 1.80 & 1.86 & 1.73 & 1.79 \\
\hline$X_{\mathrm{Al}}$ & 0.39 & 0.38 & 0.38 & 0.39 & 0.41 & 0.40 & 0.40 & 0.41 & 0.41 & 0.40 & 0.34 & 0.31 & 0.35 & 0.33 \\
\hline$X_{\mathrm{Fe}}$ & 0.47 & 0.50 & 0.51 & 0.42 & 0.42 & 0.43 & 0.47 & 0.42 & 0.40 & 0.44 & 0.46 & 0.57 & 0.47 & 0.49 \\
\hline
\end{tabular}

* All Fe calculated as FeO. Phengite normalized to 12 IV and VI cations, and biotite to 22 oxygens. Two standard deviations on the basis of counting statistics are $0.11-0.15$ pfu for $\mathrm{Si}$, $0.01 \mathrm{pfu}$ for $\mathrm{Ti}$ and $\mathrm{Ca}, 0.02-0.04 \mathrm{pfu}$ for $\mathrm{Na}$, and $0.10-0.15 \mathrm{pfu}$ for $\mathrm{K}$ for both phengite and biotite. Two standard deviations are $0.10-0.14 \mathrm{pfu}$ for $\mathrm{Al}, 0.01-0.03 \mathrm{pfu}$ for $\mathrm{Fe}$, $0.01-0.05 \mathrm{pfu}$ for $\mathrm{Mg}$ for phengite, and $0.05-0.09$ pfu for $\mathrm{Al}, 0.15-0.23$ pfu for $\mathrm{Fe}, 0.12-0.20$ pfu for $\mathrm{Mg}$, and $0.01-0.02$ pfufor $\mathrm{Mn}$ for biotite, respectively. $\Sigma \mathrm{A}$, total interlayer cations. $X_{\mathrm{Al}}=\mathrm{Al} /(\mathrm{Al}+\mathrm{Si})$ $X_{\mathrm{Fe}}=\mathrm{Fe} /(\mathrm{Fe}+\mathrm{Mg}) . * *$ Average of more than $20 \mathrm{AEM}$ analyses. ${ }^{* * *}$ n.d., not detected.

fine-grained, it is well developed in many metagreywackes and metabasites (e.g. Robinson, 1958; Adams \& Robinson, 1993) from near Watsons Beach (Fig. 2) northwards. A stilpnomelane occurrence in pelite still further south at Chrystalls Beach has been reported by Kisch (1981). The most southerly occurrences are within the area of uncertain low-grade facies affinity, lacking diagnostic assemblages for either prehnitepumpellyite or pumpellyite-actinolite facies. In northern Otago, Bishop (1972) recorded stilpnomelane in metagreywackes ranging from the prehnite-pumpellyite facies, TZ I, to the chlorite zone of the greenschist facies, TZ IIIA, those from the prehnite-pumpellyite facies being near the prehnite-out isograd. This appears to be typical for the Haast Schist of southern New Zealand, and is compatible with the occurrences in the south-eastern Otago section.

Most stilpnomelane-bearing rocks reported near and south of Akatore Creek are relatively coarse-grained and of more highly metamorphic aspect than nonstilpnomelane-bearing rocks at the same locations. In addition to metamorphic grade and bulk-rock composition controls, reactions forming stilpnomelane may be promoted by higher permeability and effective water/rock ratio in coarser-grained rocks. Inhibition of mineral reactions in fine-grained rocks of inferred low permeability has been reported in the zeolite facies (Boles \& Coombs, 1977; Li et al., 1997).

\section{Relation of phyllosilicate compositions to metamorphic grade and equilibrium}

The composition of metamorphic minerals is a function of the extent to which equilibrium is reached, as well as the $P-T$ conditions and bulk rock composition, more particularly the chemical components that are available for reaction. These may be provided by fluids as well as by pre-existing minerals, which include relict detrital grains in the lower-grade rocks.

Among the phyllosilicates of the present study, chlorite varies most in chemical composition, with $\mathrm{Fe} /(\mathrm{Fe}+\mathrm{Mg})$ ratios ranging from 0.53 to 0.72 . The ratios observed in two greenschist facies TZ IIIB rocks are substantially lower than those in stilpnomelanefree sample D8.2 (TZ IIA) and in stilpnomelanebearing sample D6 (TZ IIB). The amount of chlorite decreases with increasing metamorphic grade, and no chlorite was detected in some pumpellyite-actinolite facies rocks. In the prehnite-pumpellyite facies of northern Otago, chlorite is Fe-rich, and at higher grades that in metagreywackes is less Fe-rich (Bishop, 1972). A decrease of $\mathrm{Fe} /(\mathrm{Fe}+\mathrm{Mg})$ in chlorite with increasing metamorphic grade has been widely reported for differing lithologies, physical conditions and mineral reactions (e.g. Cooper, 1972; Terabayashi, 1988; Springer et al., 1992). Other data show a contrary trend or no relationship (Beiersdorfer \& Day, 1995). Brown (1967) found chlorite within the biotite zone of eastern Otago with $\mathrm{Fe} /(\mathrm{Fe}+\mathrm{Mg})$ ratios ranging from 0.44 to 0.77. de Caritat et al. (1993) emphasized the effect of oxygen fugacity on $\mathrm{Fe} /(\mathrm{Fe}+\mathrm{Mg})$ of chlorite, with higher $\mathrm{Fe} /(\mathrm{Fe}+\mathrm{Mg})$ being favoured by lower $f_{\mathrm{O}_{2}}$ values. Coombs et al. (1996) found a much greater range in $\mathrm{Fe} /(\mathrm{Fe}+\mathrm{Mg})$ ratios $(0.26-0.92)$ in chlorite of intimately associated prehnite-pumpellyite facies metapelagites than the entire range of the present study; hematite-bearing rocks have chlorite with high $\mathrm{Mg} /(\mathrm{Fe}+\mathrm{Mg})$, whereas in rocks of lower oxidation state it has a higher $\mathrm{Fe} /(\mathrm{Fe}+\mathrm{Mg})$. Clearly, the available $\mathrm{Fe}^{2+} /\left(\mathrm{Fe}^{2+}+\mathrm{Mg}\right)$ is the major factor in controlling that ratio in chlorite and other phyllosilicates. It is itself a function of bulk-rock composition and $f_{\mathrm{O}_{2}}$. 
Alteration of smectite and decomposition of Fe-rich detrital biotite and chlorite are common sources of $\mathrm{Fe}$ and $\mathrm{Mg}$ in diagenetic and metamorphic chlorite, and are inferred to be probable sources of chlorite in the low-grade, stilpnomelane-free rocks of this study. Regardless of the origin of low-grade chlorite, however, the collective data, including textural relations among co-existing minerals as defined by TEM, imply that stilpnomelane formed at the expense of such chlorite, which contributed $\mathrm{Fe}$ and $\mathrm{Mg}$ to both neoformed phengite and stilpnomelane. In the lowest-grade stilpnomelane-bearing samples, stilpnomelane has a high $\mathrm{Fe} /(\mathrm{Fe}+\mathrm{Mg})$ ratio. As with chlorite, stilpnomelane in chlorite zone TZ IIIB contains less Fe and more $\mathrm{Mg}$ than in lower-grade rocks.

Partition of $\mathrm{Fe}$ and $\mathrm{Mg}$ between the phyllosilicates of the present study is nearly constant from sample to sample in TZ II to TZ IIIB. Averaged co-existing mineral pair analyses yield $\mathrm{Fe} / \mathrm{Mg} K_{\mathrm{D}}(\mathrm{Stp} / \mathrm{Chl}) \approx 2.5$, $K_{\mathrm{D}}(\mathrm{Stp} / \mathrm{Phe}) \approx 4.2$, and $K_{\mathrm{D}}(\mathrm{Chl} / \mathrm{Phe}) \approx 1.9$. Iron is thus partitioned strongly into stilpnomelane relative to chlorite and phengite, and into chlorite relative to phengite. Such distribution coefficients are usually independent of composition but may vary with temperature. Our analyses of chlorite-stilpnomelane pairs yield similar $K_{\mathrm{D}}$ values to those of pairs from the greenschist facies from further north in East Otago (Brown, 1967). These observations suggest that a close approach to equilibrium has been maintained between the co-existing phyllosilicates.

\section{Formation of stilpnomelane}

Chlorite is widespread in the Otago Schist. It occurs in much smaller proportions in stilpnomelane-bearing rocks, and it was not found even at the TEM scale of observation in some specimens from the chlorite zone, TZ IIIA. Nanometre-sized relict chlorite is armoured within relatively thick phengite packets in stilpnomelane-bearing rocks of the pumpellyite-actinolite facies. In addition, there are step-like crystal boundaries between relict chlorite and surrounding phengite crystals, consistent with a reaction boundary. The chlorite that was found associated with stilpnomelane displays unique textures. TEM lattice-fringe images show small numbers of $14 \AA$ chlorite layers within dominant stilpnomelane and apparent transformations of these chlorite layers to $12 \AA$ stilpnomelane layers. The chlorite layers are inferred to be relict. Defectbearing stilpnomelane lamellae were observed in areas showing reaction rims in contact with chlorite. The subparallel boundaries between chlorite and stilpnomelane are commonly associated with dislocations (layer terminations), and appear to have resulted from dissolution of precursor chlorite and precipitation of stilpnomelane. Such boundaries are inferred to have served as conduits for the transport of fluid and ions during modification of stilpnomelane by dissolution and crystallization, as implied by defect-free stilpnomelane layers away from the reaction front.

Reactions that have been proposed to form stilpnomelane with chlorite as a reactant include:

$$
\begin{gathered}
\text { chlorite }+ \text { hematite }+ \text { quartz }+\mathrm{H}_{2} \mathrm{O} \\
=\text { stilpnomelane }\left(+\mathrm{O}_{2}\right)(\text { Iwasaki, 1963) } \\
\text { chlorite }+ \text { magnetite }+ \text { quartz }+\mathrm{H}_{2} \mathrm{O} \\
=\text { stilpnomelane }+\mathrm{O}_{2}(\text { Brown, } 1967) \\
\text { K-feldspar }+ \text { chlorite }=\text { stilpnomelane } \\
+ \text { muscovite }+\mathrm{H}_{2} \mathrm{O} \text { (Bishop, 1972) }
\end{gathered}
$$

glauconite + quartz \pm chlorite $=$ stilpnomelane

$$
+\mathrm{K} \text {-feldspar }+\mathrm{H}_{2} \mathrm{O}+\mathrm{O}_{2} \text { (Frey et al., 1973) }
$$

As glauconite has not been observed in rocks of this study, it is excluded as a major source of $\mathrm{K}$ in pelitic rocks of south-eastern Otago, and reaction (4) may be ruled out. Alteration of detrital biotite to chlorite, titanite and other phases is usually complete by about the I-IIA isotect, i.e. a little after the first appearance of stilpnomelane (Bishop, 1972), and is another potential source of $\mathrm{K}$. Nonetheless, we infer that authigenic phengite and detrital white mica are major sources of $\mathrm{K}$ for the formation of stilpnomelane in metapelites of the present study. Phengite evolved from illite (Li, 1996), and some is probably an alteration product of detrital K-feldspar (Coombs et al., 1996). Growth of stilpnomelane at the expense of chlorite is supported by the present study. On the other hand, where, as often observed, stilpnomelane overprints the early textures with sprays of crystals of habit quite different from that of pre-existing chlorite, the mechanism for its growth cannot have been by grain-boundary replacement as revealed by some TEM images, but rather by precipitation of components transported in solution, as in the case of partial replacement of K-feldspar. Stilpnomelane that formed from precursor chlorite has been observed in other localities. In the Central Alps, stilpnomelane formed in low-grade metapelitic rocks by reaction of chlorite and is favoured by low $\mathrm{fO}_{2}$ (Frey et al., 1973). In prehnite-pumpellyite facies metabasites of Flin Flon domain, Manitoba, Canada, chlorite is absent from rocks with stilpnomelane (Digel \& Gordon, 1995).

Some of the Otago stilpnomelane is associated with $\mathrm{K}$-feldspar, a detrital mineral which is not found in the lower-grade portions of the pumpellyite-actinolite facies (Bishop, 1972). In the south-eastern Otago coastal section, relict detrital K-feldspar is preserved in metagreywackes at least as far north as Taieri Mouth (Suzuki \& Suzuki, 1988). In a metagreywacke sample (OU61853) from the mouth of Akatore Creek, abundant stilpnomelane is in intimate contact with $\mathrm{K}$-feldspar clasts, in some cases being preferentially emplaced within potassic lamellae in perthite and spreading from fractures. Even though little or no 
chlorite remains in this rock, reaction (3) may represent a relevant stilpnomelane-forming reaction. Growth of stilpnomelane within K-feldspar requires local transport of $\mathrm{Fe}$ and $\mathrm{Mg}$ in solution. Although not identified in the observed metapelites, clasts of K-feldspar smaller than those of the sandstones would have been present in parental siltstones. However, application of the ferrostilpnomelane formula from Miyano \& Klein (1989) would require that $\mathrm{H}_{2} \mathrm{O}$ be located on the opposite side of reaction (3) from stilpnomelane:

$$
\begin{gathered}
266 \mathrm{KAlSi}_{3} \mathrm{O}_{8}+192 \mathrm{Fe}_{5} \mathrm{Al}_{2} \mathrm{Si}_{3} \mathrm{O}_{10}(\mathrm{OH})_{8} \\
+388 \mathrm{SiO}_{2}+84 \mathrm{H}_{2} \mathrm{O} \\
=20 \mathrm{~K}_{5} \mathrm{Fe}_{48} \mathrm{Al}_{8} \mathrm{Si}_{64} \mathrm{O}_{168}(\mathrm{OH})_{45} \cdot 12 \mathrm{H}_{2} \mathrm{O} \\
+81 \mathrm{~K}_{2} \mathrm{Al}_{6} \mathrm{Si}_{6} \mathrm{O}_{20}(\mathrm{OH})_{4}
\end{gathered}
$$

$$
\begin{gathered}
202 \mathrm{KAlSi}_{3} \mathrm{O}_{8}+192 \mathrm{Fe}_{5} \mathrm{Al}_{2} \mathrm{Si}_{3} \mathrm{O}_{10}(\mathrm{OH})_{8} \\
+194 \mathrm{SiO}_{2}+66 \mathrm{H}_{2} \mathrm{O} \\
=20 \mathrm{~K}_{5} \mathrm{Fe}_{48} \mathrm{Al}_{8} \mathrm{Si}_{64} \mathrm{O}_{168}(\mathrm{OH})_{45} \cdot 12 \mathrm{H}_{2} \mathrm{O} \\
+81 \mathrm{~K}_{2} \mathrm{FeAl}_{4} \mathrm{Si}_{7} \mathrm{O}_{20}(\mathrm{OH})_{4}
\end{gathered}
$$

Reaction (5a) is balanced with ideal muscovite and reaction (5b) with ideal ferrophengite, which is more appropriate to the composition of Otago phengite (Table 4). A similar result would be obtained from Eggleton \& Chappell's (1978) formula, but it is not used because it is not charge-balanced for anions.

The presence of water on the reactant side of the equations makes it unlikely that these represent prograde formation of stilpnomelane by an equilibrium process. Formation of ferrostilpnomelane by hydration would require that the $P-T$ path of prograde metamorphism is steeper than the slope of reactions (5a) and (5b). Although this cannot be ruled out, hydration reactions are rare during prograde metamorphism of metapelites. The calculations of Miyano \& Klein (1989) using the stilpnomelane formula of equation (5a) yielded no flat or backbending stilpnomelane reactions at low to moderate pressures, and there is no evidence of especially large pressure gradients in Otago. However, the $\mathrm{H}_{2} \mathrm{O}$ content of stilpnomelane is not well defined and if it is less than that given above, or if $\mathrm{Fe}^{3+}$ is matched with decreased hydroxyl in the stilpnomelane, then free water may occur on the product side of the equations. Reactions (5a) and (5b) can therefore be converted to reactions without free water in the system KFASH as follows:

$$
\begin{gathered}
266 \mathrm{KAlSi}_{3} \mathrm{O}_{8}+192 \mathrm{Fe}_{5} \mathrm{Al}_{2} \mathrm{Si}_{3} \mathrm{O}_{10}(\mathrm{OH})_{8}+388 \mathrm{SiO}_{2} \\
=20 \mathrm{~K}_{5} \mathrm{Fe}_{48} \mathrm{Al}_{8} \mathrm{Si}_{64} \mathrm{O}_{168}(\mathrm{OH})_{45} \cdot 8.3 \mathrm{H}_{2} \mathrm{O} \\
+81 \mathrm{~K}_{2} \mathrm{Al}_{6} \mathrm{Si}_{6} \mathrm{O}_{20}(\mathrm{OH})_{4}
\end{gathered}
$$

$$
\begin{aligned}
& 202 \mathrm{KAlSi}_{3} \mathrm{O}_{8}+93 \mathrm{Fe}_{5} \mathrm{Al}_{2} \mathrm{Si}_{3} \mathrm{O}_{10}(\mathrm{OH})_{8}+194 \mathrm{SiO}_{2} \\
& =20 \mathrm{~K}_{5} \mathrm{Fe}_{48} \mathrm{Al}_{8} \mathrm{Si}_{64} \mathrm{O}_{168}(\mathrm{OH})_{45} \cdot 3.75 \mathrm{H}_{2} \mathrm{O} \\
& +81 \mathrm{~K}_{2} \mathrm{FeAl}_{4} \mathrm{Si}_{7} \mathrm{O}_{20}(\mathrm{OH})_{4} \\
& 202 \mathrm{KAlSi}_{3} \mathrm{O}_{8}+192 \mathrm{Fe}_{5} \mathrm{Al}_{2} \mathrm{Si}_{3} \mathrm{O}_{10}(\mathrm{OH})_{8} \\
& +388 \mathrm{SiO}_{2}+42 \mathrm{O}_{2} \\
& =20 \mathrm{~K}_{5} \mathrm{Fe}^{2+}{ }_{39.6} \mathrm{Fe}^{3+}{ }_{8.4} \mathrm{Al}_{8} \mathrm{Si}_{64} \mathrm{O}_{176.4}(\mathrm{OH})_{36.6} \cdot 12 \mathrm{H}_{2} \mathrm{O} \\
& +81 \mathrm{~K}_{2} \mathrm{Al}_{6} \mathrm{Si}_{6} \mathrm{O}_{20}(\mathrm{OH})_{4} \\
& 202 \mathrm{KAlSi}_{3} \mathrm{O}_{8}+93 \mathrm{Fe}_{5} \mathrm{Al}_{2} \mathrm{Si}_{3} \mathrm{O}_{10}(\mathrm{OH})_{8} \\
& +194 \mathrm{SiO}_{2}+33 \mathrm{O}_{2} \\
& =8 \mathrm{~K}_{5} \mathrm{Fe}^{2+}{ }_{31.5} \mathrm{Fe}^{3+}{ }_{16.5} \mathrm{Al}_{8} \mathrm{Si}_{64} \mathrm{O}_{168}(\mathrm{OH})_{28.5} \cdot 12 \mathrm{H}_{2} \mathrm{O} \\
& +81 \mathrm{~K}_{2} \mathrm{FeAl}_{4} \mathrm{Si}_{7} \mathrm{O}_{20}(\mathrm{OH})_{4}
\end{aligned}
$$

Any greater diminution of $\mathrm{H}_{2} \mathrm{O}$ or $\mathrm{OH}$ in Fe-stilpnomelane would allow it to form by a dehydration reaction from chlorite, $\mathrm{K}$-feldspar and quartz. Hence only $\mathrm{H}_{2} \mathrm{O}$-depleted and/or $\mathrm{OH}$-depleted ferrian stilpnomelane is expected to form with phengite from $\mathrm{K}$-feldspar and chlorite under prograde equilibrium conditions. Ferrian stilpnomelane is favoured by more oxidizing conditions relative to the more reduced chlorite side of the reaction. The product side of the above $\mathrm{H}_{2} \mathrm{O}$-free reactions is favoured by increasing pressure because of the presence of voluminous $\mathrm{K}$-feldspar and quartz on the reactant side. Reactions involving other stilpnomelane and phengite compositions in the system KFASHO can be derived by algebraic combination of reactions (5)-(7).

With variable $\mathrm{H}_{2} \mathrm{O}, \mathrm{OH}$, and $\mathrm{Fe}^{3+}$ contents, the orientation of the stilpnomelane reaction curves will rotate and shift in $P-T$ space such that the locus of a stilpnomelane-in reaction may correspond to that of a stilpnomelane-out reaction for a different oxidation and hydration state. The exact oxidation and hydration states of stilpnomelane at the time it grew are thus critical parameters to be established in order to identify the reaction by which it formed. The stoichiometry of the above reactions is also sensitive to the $\mathrm{K}$ content assumed for the stilpnomelane. These parameters are all difficult to measure and are susceptible to the subsequent alteration and weathering history of this mineral. Moreover, variation in these parameters may control the formation, loss or lack of appearance of stilpnomelane in adjacent lithologies with variable oxidation states. It will be no easy task to establish the exact reactions controlling the appearance and breakdown of stilpnomelane in metapelites and metabasites.

Chlorite is clearly the major source of $\mathrm{Fe}$ and $\mathrm{Mg}$ in the lower-grade rocks of the present study. However, for those stilpnomelane-rich rocks in which little or no chlorite remains, chlorite with or without phengite could not have provided sufficient Fe to form stilpnomelane, which has a substantially higher $\mathrm{Fe} /(\mathrm{Fe}+\mathrm{Mg})$ 
ratio than either of these other minerals. Phengite, which is ubiquitous in all the rocks studied, contains $30-40 \%$ celadonite component, which cannot validly be neglected in A'FM plots. Such plots have therefore been constructed (Fig. 10) with all minerals projected (Thompson, 1957) from excess $\mathrm{SiO}_{2}, \mathrm{H}_{2} \mathrm{O}$ and phengite rather than muscovite components. The stilpnomelane plots nearly astride the FM join in these projections, whereas it falls well below it when projected from ideal $\mathrm{KAl}_{3} \mathrm{Si}_{3} \mathrm{O}_{10}(\mathrm{OH})_{2}$ in the standard $\mathrm{A}^{\prime} \mathrm{FM}$ plot. The disadvantage of projecting from phengite is that the orientation of the tie lines projected onto the diagram and even the tie lines between co-existing minerals may also vary with the amount of phengite solid solution. That is also a major flaw of traditional ACF diagrams projected from $\mathrm{NaAlSi}_{3} \mathrm{O}_{8}$ and applied to assemblages with plagioclase of variable An content. Here the celadonite composition is approximately constant, and the diagram is not strongly perturbed. Nonetheless, assemblages predicted on this $\mathrm{A}^{\prime} \mathrm{FM}$ diagram may change for bulk compositions with muscovite of a low celadonite content.

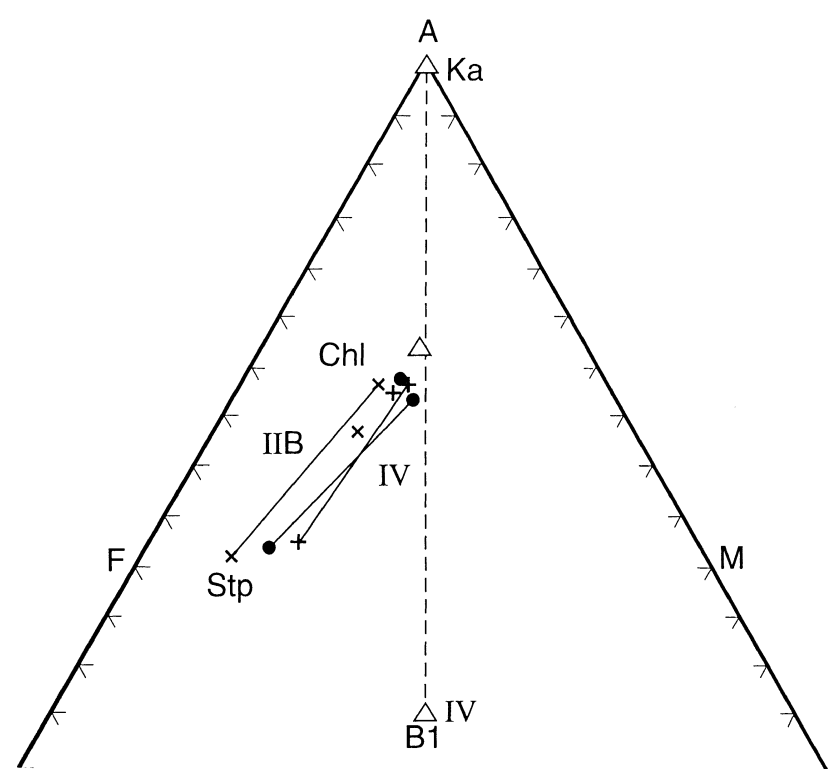

Fig. 10. A'FM diagram showing tie lines for phyllosilicates from TZ IIB (D6: $\times$ ) and TZ IIIB (D2, O; D33: +; D1.3: $\triangle)$. All iron is assumed to be ferrous in the chlorite, stilpnomelane and biotite for this projection. The same symbols not connected with lines represent bulk-rock compositions projected from phengite, $\mathrm{NaAlO}_{2}, \mathrm{SiO}_{2}$ and $\mathrm{H}_{2} \mathrm{O}$ as $\mathrm{A}^{\prime} \mathrm{FM}\left(-\mathrm{NaAlO}_{2}\right)$, also assuming only ferrous iron. The projections of the rock compositions plot close to the tie lines for the phyllosilicate assemblages. The remaining differences between the tie lines and the bulk-rock projection are related to the presence of epidote, magnetite, pyrite and iron carbonate in the rocks (Table 1). The tie line for kaolinite-biotite (D1.3) is dashed because it is not an equilibrium assemblage, although the projection of the bulk rock composition lies close to that tie line. The TZ IIIB samples are more magnesian than those from TZ IIB. The solid tie lines represent the assemblage chlorite-stilpnomelane-phengite-albite-quartz- $\mathrm{H}_{2} \mathrm{O}$ in the system KNMFASH.
Formation of stilpnomelane could be initiated by a continuous reaction such as:

$$
\begin{gathered}
\text { chlorite }+ \text { phengite }+ \text { quartz }=\text { stilpnomelane }+ \text { chlorite } \\
+ \text { phengite } \pm \mathrm{H}_{2} \mathrm{O}
\end{gathered}
$$

where the products chlorite and phengite have a lower $\mathrm{Fe} /(\mathrm{Fe}+\mathrm{Mg})$ ratio than the equivalent reactants. Whether $\mathrm{H}_{2} \mathrm{O}$ lies on the reactant or product side of reaction (8) depends critically on the $\mathrm{K}, \mathrm{Fe}^{3+} / \mathrm{Fe}^{2+}$, $\mathrm{O} / \mathrm{OH}$ and $\mathrm{H}_{2} \mathrm{O}$ contents of the stilpnomelane that is formed. As this reaction proceeds, the ratio $\mathrm{Fe} /(\mathrm{Fe}+\mathrm{Mg})$ would progressively decrease in all three phases. However, with the distribution coefficients observed, chlorite and phengite could not have provided sufficient $\mathrm{Fe}$ for those stilpnomelane-rich rocks in which little or no chlorite remains unless there are significant differences in bulk rock composition. This suggests a reaction involving an additional source of Fe. A discontinuous reaction in which chlorite, phengite, quartz, and a source of iron such as hematite, magnetite, pyrite or siderite may be involved. Pyrite, magnetite and siderite have all been observed in both stilpnomelane-bearing metagreywacke and metapelites from the study area. An alternative reaction forming stilpnomelane is thus as follows:

$$
\begin{aligned}
& \text { chlorite }+ \text { magnesian phengite }+ \text { magnetite }+ \text { quartz } \\
& =\text { stilpnomelane }+ \text { ferroan phengite }+\mathrm{O}_{2} \pm \mathrm{H}_{2} \mathrm{O}
\end{aligned}
$$

Analogous reactions may be written with hematite, pyrite or siderite. Reactions (8) and (9) are similar to reactions (1) and (2) in that chlorite and magnetite react to form stilpnomelane, except that phengite is included as a necessary source of $\mathrm{K}$. Unweathered stilpnomelane in the south-east Otago section, like that described by Brown (1967, 1971), is undoubtedly ferrostilpnomelane. This does not preclude substitution of some $\mathrm{Fe}^{3+}$ (Eggleton \& Chappell, 1978), and the $\mathrm{OH}, \mathrm{H}_{2} \mathrm{O}$ and $\mathrm{K}$ contents also remain uncertain, preventing calculation of a reliable balanced equation. Stilpnomelane should nonetheless be favoured by low $\mathrm{fO}_{2}$, and chlorite-phengite-quartz-hematite or chlorite-phengite-quartz-magnetite by higher $f \mathrm{O}_{2}$. Alternatively, stilpnomelane may form initially during progress of an irreversible reaction involving detrital K-feldspar grains.

In summary, several reactions are considered as applicable to the formation of stilpnomelane in the south-eastern Otago coastal section. Two mechanisms are involved, one being intimate grain-boundary replacement of chlorite preserving the approximate orientation of the precursor phyllosilicate, and the other being new growth of stilpnomelane from solution, forming sprays transverse to foliation, penetrating clasts of minerals such as K-feldspar in metagreywackes, or crystallizing in veinlets. 


\section{Formation of biotite and its relation with stilpnomelane}

Sample D1.3, collected from the biotite zone of the greenschist facies (TZ IIIB), contains no chlorite or stilpnomelane. It contains intergrown biotite and phengite, implying that the formation of biotite may be related to the breakdown of stilpnomelane. Formation of biotite by breakdown of stilpnomelane has been reported from many areas including iron formations of the Hamersley Group, Western Australia, where textures suggest that the bands now occupied by biotite may originally have been stilpnomelane (Miyano \& Miyano, 1982; Klein \& Gole, 1981). Proposed biotite-producing reactions involving stilpnomelane include the following:

muscovite + stilpnomelane + actinolite

$=$ biotite $\left(+\right.$ chlorite + epidote $\left.+\mathrm{H}_{2} \mathrm{O}\right)($ Brown, 1971 $)$

muscovite + stilpnomelane $=$ biotite $(+$ chlorite

$$
\left.+ \text { quartz }+\mathrm{H}_{2} \mathrm{O}\right)(\text { Brown, 1971) }
$$

stilpnomelane + chlorite $+\mathrm{K}$-feldspar $=$ biotite + quartz

$$
+\mathrm{H}_{2} \mathrm{O} \text { (Chatterjee, 1971) }
$$

$\mathrm{K}$-feldspar is not preserved in the TZ IIIA and IIIB rocks of the study area, and so reaction (12) is inapplicable here. Balanced reactions analogous to (5)-(7) can be derived for these reactions in the system KFASHO. An A'FM plot (Fig. 10) for biotite of TZ IIIB and stilpnomelane, chlorite and phengite of TZ IIIA suggests the reaction:

$$
\begin{aligned}
& \text { phengitic muscovite }+ \text { chlorite }+ \text { stilpnomelane } \\
= & \text { biotite }+ \text { less phengitic muscovite }+ \text { quartz }+\mathrm{H}_{2} \mathrm{O}
\end{aligned}
$$

This reaction is similar to reaction (11), except that chlorite is a reactant rather than a product. It is also possible that oxidation to magnetite, sulphidation to pyrite and/or carbonation to iron carbonate drives the compositions of stilpnomelane, chlorite and phengite into the biotite stability field. These relations imply that biotite forms in biotite-zone rocks by consumption of stilpnomelane, chlorite and phengite. The compositions of the phyllosilicates are a function of the physical conditions, oxidation state, elemental partitioning among the phases, and bulk-rock chemistry.

\section{Extended A'FM projections}

The bulk-rock composition of the host rock has also been projected onto the A'FM diagram for comparison with the plots of the co-existing minerals. The TZ IIB-IIIB semi-pelites have high Na (3.9-5.5 wt \% $\mathrm{Na}_{2} \mathrm{O}$, Table 2) represented in the mineral assemblage by nearly pure albite. If the rock composition is plotted on the $\mathrm{A}^{\prime} \mathrm{FM}$ diagram without consideration of the $\mathrm{Al}$ matched by $\mathrm{Na}$ in $\mathrm{NaAlSi}_{3} \mathrm{O}_{8}$, the rock is much more aluminous than that indicated by the A'FM assemblage. The rock composition was therefore projected from $\mathrm{NaAlSi}_{3} \mathrm{O}_{8}$ as well as from phengite, $\mathrm{SiO}_{2}$ and $\mathrm{H}_{2} \mathrm{O}$ (i.e. from phengite, $\mathrm{NaAlO}_{2}, \mathrm{SiO}_{2}$ and $\mathrm{H}_{2} \mathrm{O}$ ) in order to compare the bulk composition with the mineral compatibility space. This modified "FM diagram may be designated as $\mathrm{A}^{\prime} \mathrm{FM}$ (-phengite, $-\mathrm{NaAlO}_{2}$ ) to distinguish it from an ordinary $\mathrm{A}^{\prime} \mathrm{FM}$ diagram. The bulk composition of D6, D33 and D2 then falls close to the space indicated by the A'FM mineral assemblage (Fig. 10). The projections of D33 and D2 lie close to their chlorite points, although they are moved towards $\mathrm{A}^{\prime}$ due to the presence of epidote and towards $\mathrm{F}$ due to pyrite. The deviation of the bulk composition of D6 towards $\mathrm{M}$ may indicate a more magnesian bulk composition than that of the local assemblage that was analysed on the TEM for co-existing phengitechlorite-stilpnomelane. The bulk composition of the hydrothermally altered rock (D1.3) is highly depleted in silica and enriched in alumina, although its projection still lies close to the kaolin-biotite tie line (Fig. 10). The biotite in this rock probably formed by reaction from a much more magnesian chlorite than that from the other schists in this study. The extended A'FM diagram represents part of the system NKFMASH for assemblages with excess albite, quartz, phengite and water. This projection cannot account for detrital $\mathrm{K}$-feldspar that is still present in greywackes of lower grades. The effect of uncorrected K-feldspar is to move the bulk composition towards $\mathrm{A}^{\prime}$, i.e. towards chlorite. The bulk composition of many low-grade rocks is an inexact representation of components available for the metamorphic assemblage as a result of unreacted precursor phases.

The A'FM(-phengite, $\left.-\mathrm{NaAlO}_{2}\right)$ diagram should be considered for use in other KNFMASH rocks, such as low-grade rocks that contain albite, jadeite, glaucophane or analcite, each of which is ideally a metaluminous phase, having an $\mathrm{Na} / \mathrm{Al}$ ratio of unity. Glaucophane--magnesioriebeckite solid solutions would project along the FM join in this diagram, but the projection is not suitable for paragonite-bearing parageneses, which would require $\mathrm{NaAl}_{3} \mathrm{O}_{5}$ instead as a projection point. If lawsonite or laumontite were also present, the system could be extended to portions of the system KNCFMASH by simultaneous projection from $\mathrm{CaAl}_{2} \mathrm{O}_{4}$ for this component in lawsonite and laumontite. Such a projection, which may be designated $\mathrm{A}^{\prime} \mathrm{FM}$ (-phengite, $\left.-\mathrm{CaAl}_{2} \mathrm{O}_{4},-\mathrm{NaAlO}_{2}\right)$, would be useful because of the partitioning of $\mathrm{Na}$ and $\mathrm{Ca}$ into two different phases (albite-lawsonite or albite-laumontite) at low grades, in striking contrast to their combination into plagioclase and hornblende at higher grades. This projection may be used to describe divariant KNCFMASH assemblages such as glaucophane-chloritoid - chlorite - ( phengite-jadeitelawsonite-quartz-water) and stilpnomelane-chloritoid- 
chlorite-(phengite - albite - lawsonite - quartz water), where the phases corresponding to the projection points are in parentheses. It may, however, be an inadequate representation if the celadonite content of phengite is highly variable in adjacent lithologies. It may also fail in the presence of additional $\mathrm{Ca}$-bearing phases such as the epidote minerals, pumpellyite, omphacite, prehnite or actinolite, which lie outside the compositional range being considered in KNCFMASH. Other modified A'FM diagrams could be projected from $\mathrm{Ca}_{2} \mathrm{Al}_{2} \mathrm{O}_{5}$ for prehnite and $\mathrm{Ca}_{4} \mathrm{Al}_{6} \mathrm{O}_{13}$ for clinozoisite-bearing assemblages. A treatment of $\mathrm{Fe}^{3+}$, as is required for an understanding of epidote, riebeckite and ferristilpnomelane solid solutions, is more difficult, requiring measurement of $\mathrm{Fe}_{2} \mathrm{O}_{3} / \mathrm{FeO}$ in each of the ferromagnesian minerals. Projections from $\mathrm{Fe}_{2} \mathrm{O}_{3}$ or $\mathrm{Fe}_{3} \mathrm{O}_{4}$ could be explored if hematite or magnetite is part of the metamorphic assemblage. Extended A'FM diagrams may prove useful in the understanding of many low-grade metamorphic assemblages. As with any other projections from $n$-dimensional space, their major disadvantage is loss of generality.

\section{ACKNOWLEDGEMENTS}

D. Craw, A. N. Halliday, J. R. O’Neil, L. Warr and B. A. van der Pluijm are thanked for helpful comments on an early draft of this paper. The authors are also grateful for comments of D. Robinson and two other reviewers. This work was supported by NSF grants EAR 91-04565, EAR 87-08276, EAR 91-17772 and BSR 83-14092. The contribution of D.S.C. was supported by the New Zealand Foundation for Research, Science and Technology. This paper is contribution no. 514 from the Mineralogical Laboratory, University of Michigan.

\section{REFERENCES}

Adams, C. J. \& Robinson, P., 1993. Potassium-argon age studies of metamorphism/uplift/cooling in Haast Schist coastal sections south of Dunedin, Otago, New Zealand. New Zealand Journal of Geology and Geophysics, 36, 317-325.

Ahn, J. H. \& Peacor, D. R., 1987. Kaolinitization of biotite: TEM data and implications for an alteration mechanism. American Mineralogist, 72, 353-356.

Ahn, J. H., Peacor, D. R. \& Essene, E. J., 1986. Cation-diffusioninduced characteristic beam damage in transmission electron microscope images of micas. Ultramicroscopy, 19, 375-382.

Beiersdorfer, R. E. \& Day, H. W., 1995. Mineral paragenesis of pumpellyite in low-grade mafic rocks. Geological Society of America Special Paper, 296, 5-27.

Bishop, D. G., 1972. Progressive metamorphism from prehnitepumpellyite to greenschist facies in the Dansey Pass area, Otago, NZ. Geological Society of America Bulletin, 83, 3177-3198.

Bishop, D. G., Bradshaw, J. D. \& Landis, C. A., 1985. Provisional terrane map of the South Island, New Zealand. In: Tectonostratigraphic Terranes of the Circum-Pacific Region, Volume 1 (ed. Howell, D. G.), pp. 515-521. Circum-Pacific Council for Energy and Mineral Resources, Houston, Texas.

Boles, J. R. \& Coombs, D. S., 1977. Zeolite facies alteration of sandstones in the Southland Syncline, New Zealand. American Journal of Sciences, 277, 982-1012.

Brown, E. H., 1967. The greenschist facies in part of eastern Otago, New Zealand. Contributions to Mineralogy and Petrology, 14, 259-192.

Brown, E. H., 1971. Phase relations of biotite and stilpnomelane in the greenschist facies. Contributions to Mineralogy and Petrology, 31, 275-299.

Brown, E. H., 1975. A petrographic grid for reactions producing biotite and other $\mathrm{Al}-\mathrm{Fe}-\mathrm{Mg}$ silicates in the greenschist facies. Journal of Petrology, 16, 258-271.

de Caritat, P., Hutcheon, J. \& Walshe, J. L., 1993. Chlorite geothermometry: a review. Clays \& Clay Minerals, 41, 219-239.

Chatterjee, N. D., 1971. Phase relations of biotite and stilpnomelane in the greenschist facies. Contributions to Mineralogy and Petrology, 31, 275-299.

Cliff, G. \& Lorimer, G. W., 1975. The quantitative analysis of thin specimens. Journal of Microscopy, 103, 203-207.

Coombs, D. S., Kawachi, Y. \& Ford, P. P., 1996. Porphyroblastic manganaxinite metapelagites with incipient garnet in prehnitepumpellyite facies, near Meyers Pass, Torlesse Terrane, New Zealand. Journal of Metamorphic Geology, 14, 125-142.

Cooper, A. F., 1972. Progressive metamorphism of metabasic rocks from the Haast Schist Group of southern New Zealand. Journal of Petrology, 13, 457-492.

Craw, D., 1981. Oxidation and microprobe induced potassium mobility in iron-bearing phyllosilicates from the Otago Schists, New Zealand. Lithos, 14, 49-57.

Craw, D., Coombs, D. S. \& Kawachi, Y., 1982. Interlayered biotite-kaolin and other altered biotites, and their relevance to the biotite isograd in eastern Otago, New Zealand. New Zealand Journal of Geological Magazine, 45, 79-85.

Digel, S. G. \& Gordon, T. M., 1995. Phase relations in metabasites and pressure-temperature conditions at the prehnite-pumpellyite to greenschist facies transition, Flin Flon, Manitoba, Canada. Geological Society of America Special Paper, 296, 67-80.

Eggleton, R. A. \& Chappell, B. W., 1978. The crystal structure of stilpnomelane. Part III. Chemistry and physical properties. Mineralogical Magazine, 42, 361-368.

Frey, M., Hunziker, J. C., Roggwiller, P. \& Schindler, C., 1973. Progressive neidriggradige metamorphose glaukonitführender Horizonte in den helvetischen Alpen der Ostschweiz. Contributions to Mineralogy and Petrology, 39, 185-218.

Hutton, C. O., 1938. The stilpnomelane group of minerals. Mineralogical Magazine, 25, 172-206.

Hutton, C. O. \& Turner, F. J., 1936. Metamorphic zones in western Otago. Transactions of the Royal Society of New Zealand, 65, 405-406.

Iwasaki, M., 1963. Metamorphic rocks of the Kotu-Bizan area, eastern Sikoku. Journal of the Faculty of Science, University of Tokyo, Section II, 15, 1-90.

Jamieson, R. A. \& Craw, D., 1987. Sphalerite geobarometry in metamorphic terranes: an appraisal with implications for metamorphic pressure in the Otago Schist. Journal of Metamorphic Geology, 5, 87-99.

Jiang, W.-T. \& Peacor, D. R., 1991. Transmission electron microscopic study of the kaolinitization of muscovite. Clays \& Clay Minerals, 39, 1-13.

Jiang, W.-T., Peacor, D. R. \& Buseck, P. R., 1994. Chlorite geothermometry: contamination and apparent octahedral vacancies. Clays \& Clay Minerals, 42, 593-605.

Kisch, H. J., 1981. Coal rank and illite crystallinity associated with the zeolite facies of Southland and the pumpellyitebearing facies of Otago, southern New Zealand. New Zealand Journal of Geology and Geophysics, 24, 349-360.

Klein, C. \& Gole, M. J., 1981. Mineralogy and petrology of parts of the Marra Mamba Iron Formation, Hamersley Basin, Western Australia. American Mineralogist, 66, 507-525.

Li, G., 1996. Evolution of phyllosilicates through diagenesis and low-grade metamorphism in a prograde sequence of pelitic rocks from Southern New Zealand. PhD Thesis, University of Michigan, Ann Arbor, Michigan, USA. 
Li, G., Peacor, D. R., Merriman, R. J., Roberts, B. \& van der Pluijm, B. A., 1994. TEM and AEM constraints on the origin and significance of chlorite-mica stacks in slates: an example from central Wales, U.K. Journal of Structural Geology, 16, $1139-1157$.

Li, G., Peacor, D. R. \& Coombs, D. S., 1997. Transformation of smectite to illite in bentonite and associated sediments from Kaka Point, New Zealand: contrast in rate and mechanism. Clays \& Clay Minerals, 45, 54-67.

Miyano, T. \& Klein, C., 1989. Phase equilibria in the system $\mathrm{K}_{2} \mathrm{O}-\mathrm{FeO}-\mathrm{MgO}-\mathrm{Al}_{2} \mathrm{O}_{3}-\mathrm{SiO}_{2}-\mathrm{H}_{2} \mathrm{O}-\mathrm{CO}_{2}$ and the stability limit of stilpnomelane in metamorphosed Precambrian ironformations. Contributions to Mineralogy and Petrology, 102, $478-491$.

Miyano, T. \& Miyano, S., 1982. Ferri-annite from the Dales Gorge Member iron-formations, Wittenoom area, Western Australia. American Mineralogist, 67, 1179-1194.

Mortimer, N., 1993. Geology of the Otago Schist and adjacent rocks, Scale 1:500,000. Institute of Geological \& Nuclear Sciences Geological Map 7. Institute of Geological \& Nuclear Sciences Ltd, Lower Hutt, New Zealand.

Peacor, D. R., 1992. Analytical electron microscopy: X-ray analysis. Reviews in Mineralogy, 27, 113-140.

van der Pluijm, B. A., Lee, J. H. \& Peacor, D. R., 1988. Analytical electron microscopy and the problem of potassium diffusion. Clays \& Clay Minerals, 36, 498-504.

Robinson, P., 1958. The structural and metamorphic geology of the Brighton-Taieri Mouth area, East Otago, New Zealand. MSc Thesis, University of Otago, Dunedin, New Zealand.

Roser, B. P. \& Cooper, A. F., 1990. Geochemistry and terrane affiliation of Haast Schist from the western Southern Alps, New Zealand. New Zealand Journal of Geology and Geophysics, 33, $1-10$.

Springer, R. K., Day, H. W. \& Beiersdorfer, R. E., 1992. Prehnite-pumpellyite to greenschist facies transition, Smartville Complex, near Auburn, California. Journal of Metamorphic Geology, 10, 147-170.

Suzuki, M. \& Suzuki, T., 1988. Two types of sandstone along the coast from Quoin Point to Taieri Mouth, South Island, New Zealand. In: Preliminary Report on the Accretion Complex Geology of Otago Coast Section in South Island, New Zealand (No. 1) (ed. Suzuki, T.), pp. 7-30. Co-operative Research Group of Japan and New Zealand.

Terabayashi, M., 1988. Actinolite-forming reaction at low pressure and the role of $\mathrm{Fe}^{2+}-\mathrm{Mg}$ substitution. Contributions to Mineralogy and Petrology, 100, 268-280.

Thompson, J. B., 1957. The graphical analysis of mineral assemblages in pelitic schists. American Mineralogist, 42, 842-888.

Turner, F. J., 1933. The metamorphic and intrusive rocks of southern Westland. Transactions of the New Zealand Institute, 63, 178-184.

Turner, F. J., 1935. Metamorphism of the Te Anau Series in the region north-west of Lake Wakatipu. Transactions of the Royal Society of New Zealand, 65, 329-350.

Yardley, B. W. D., 1982. The early metamorphic history of the Haast schist and related rocks of New Zealand. Contributions to Mineralogy and Petrology, 81, 317-327.

Received 17 August 1997; revision accepted 14 January 2000. 